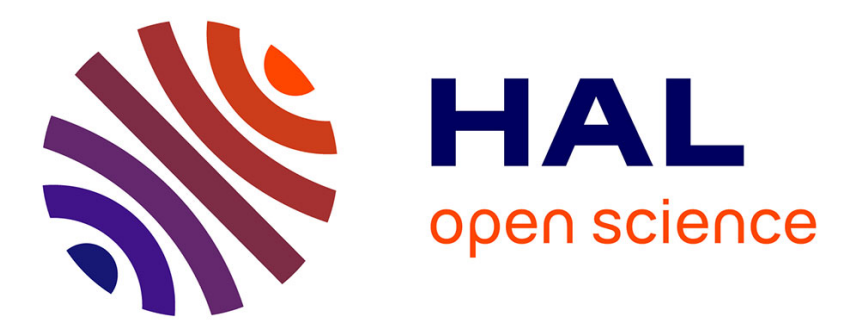

\title{
Liquid Biopsy Based on Circulating Cancer-Associated Cells: Bridging the Gap from an Emerging Concept to a Mainstream Tool in Precision Medicine
}

Alejandro Kayum Jimenez Zenteno, Aline Cerf

\section{- To cite this version:}

Alejandro Kayum Jimenez Zenteno, Aline Cerf. Liquid Biopsy Based on Circulating CancerAssociated Cells: Bridging the Gap from an Emerging Concept to a Mainstream Tool in Precision Medicine. Advanced Biosystems, 2020, 4 (2), pp.1900164. 10.1002/adbi.201900164 . hal-03098405

\author{
HAL Id: hal-03098405 \\ https://hal.science/hal-03098405
}

Submitted on 6 Jan 2021

HAL is a multi-disciplinary open access archive for the deposit and dissemination of scientific research documents, whether they are published or not. The documents may come from teaching and research institutions in France or abroad, or from public or private research centers.
L'archive ouverte pluridisciplinaire HAL, est destinée au dépôt et à la diffusion de documents scientifiques de niveau recherche, publiés ou non, émanant des établissements d'enseignement et de recherche français ou étrangers, des laboratoires publics ou privés. 


\section{WILEY-VCH}

Liquid biopsy based on circulating cancer-associated cells: bridging the gap from an emerging concept to a mainstream tool in precision medicine.

\section{Alejandro Kayum Jiménez-Zenteno and Aline Cerf*}

Dr. A. K. J. Z, Dr. A. C

LAAS-CNRS, Université de Toulouse, CNRS, 7 Avenue du Colonel Roche, 31400 Toulouse, France.

E-mail: acerf@laas.fr

Keywords: Liquid biopsy, circulating tumor cells, precision medicine, biomarkers, oncology

The concept of liquid biopsy and the isolation and analysis of circulating biomarkers from blood samples, has been proposed as a surrogate to solid biopsies and could have the potential to revolutionize the management of cancer patients. The relevance of circulating tumor cells (CTCs) and the importance of the information they carry is acknowledged by the medical community. But what are the barriers to clinical adoption? This review draws a panorama of the biological implications of CTCs, their physical and biochemical properties and the current technological bottlenecks for their analysis in relation with the medical needs. Keys and considerations to bridge the technological and clinical gaps that still need to be overcomed to be able to introduce CTCs in clinical routine are finally synthesized.

\section{Introduction}

Cancer is referred as a generic term for a large group of related diseases characterized by the continual and unregulated proliferation of cells. It is believed that cancer onset is the result from a series of genetic changes directly linked with cell division and growth deregulation. Cells growing in an uncontrolled manner invade normal tissues and organs resulting in an abnormal neoplasm formation, commonly referred as tumor. A tumor is considered as malignant when it 


\section{WILEY-VCH}

is capable of both invading surrounding normal tissue and spreading throughout the body. Although the formation of a tumor in a primary site implies a health risk for patients, the formation of distant metastases is the deadliest phase of cancer progression. Patients with metastatic disease often present one or more clinically detectable micrometastatic/macrometastatic foci. However, it is likely that many others could be present but not detectable.

Currently the spreading of cancer, or metastasis, is impossible to prevent and treatments at this stage of the disease are much less successful. One of the reasons of the poor outcome of treatments is that current treatment strategies are usually based on the pathological and molecular analysis of tissue biopsies obtained from the primary tumor and not from the overall setting including metastatic lesions. Diagnosis based on the analysis of a single-tumor biopsy is not always accurate, as it only reflects a single point in time of the whole intratumoral heterogeneity, and limits its application for prognosis and for the evaluation of treatment efficacy. ${ }^{[1]}$ Given this context, there is a clinical need for repeated biopsies at different timepoints and tissues, which is often impractical and represents a risk for the patient, in order to access to the cancer-related biological information that could improve the clinical management of patients.

The field of oncology is in a continuous quest for reliable biomarkers that could provide relevant information for diagnosis, risk stratification and prognosis of patients. Moreover, cancer biomarkers could also be analyzed to predict response to treatment and enable monitoring of disease progression. Ultimately, cancer biomarkers have the potential to be used for early detection of cancer. ${ }^{[2,3]}$ In order to significantly improve the clinical management of patients and disease outcome, those biomarkers must be easily obtained and analyzed in clinical settings in a consistent, less invasive, and repeated manner. As cancer biomarkers play a critical role in all stages of cancerous pathology, efforts have focused on investigating the biological material of diverse biological body fluids such as blood, urine, saliva, seminal plasma, 


\section{WILEY-VCH}

cerebrospinal fluid, to name a few. ${ }^{[4,5]}$ In this context, cancer biomarkers, at the cellular and molecular level, carried by the bloodstream, have given rise to the emerging concept of liquid biopsy. Liquid biopsy arises as a minimally invasive approach fitting into current clinical practice and offering advantages over traditional tissue biopsies such as increased temporal and spatial representativeness of the heterogeneity of solid tumors, and more frequent sampling. ${ }^{[6]}$ These added features would mainly enable real-time monitoring of the disease and study of the biological behavior of the tumor, particularly valuable during disease follow-up for the application of a treatment plan tailored at the patient scale which the community now refers to as precision medicine.

In this review, we address the most common blood-based biomarkers, in the field of liquid biopsy, having clinically-applicable potential, with a particular emphasis on one class of bloodbased biomarker: circulating tumor cells (CTCs).

\section{Tumor progression and cancer dissemination pathway}

The development of a tumor is a multistep process as a consequence of multiple abnormalities which accumulate over time. Tumor onset is thought to be the result of a genetic alteration at the cellular level. Broadly, malignant cells will proliferate and interact with many other surrounding cells forming what is known as tumor microenvironment. This heterogeneous cellular environment contains cells of the immune system, fibroblasts, vasculature and lymphatic nodes, as well as extracellular matrix. ${ }^{[7]}$ Altogether, the latter interact in a dynamic manner but little is known about their biological interactions and functions during tumor progression even though they are widely investigated today. The net contribution of the interaction between the tumor and its microenvironment regulates, either positively or negatively, tumor survival and progression. At early stages, the microenvironment tends to exert anti-malignant functions, whereas at late stages it exerts pro-malignant ones. ${ }^{[8]}$ According to the so-called Darwinian model, tumors evolve towards greater malignancy over time 


\section{WILEY-VCH}

promoting an invasive behavior and dissemination in later stages of tumor evolution. Thus, the development of distant metastases is the final step in tumor progression. ${ }^{[9,10]}$ This model successfully explains the steps of tumor progression and it has naturally been extended to account for cancer metastasis. However, it faces conceptual problems to explain clinical observations suggesting that metastatic seeding occurs prior to the formation of an identifiable primary tumor. ${ }^{[10-13]}$ These clinical observations are the basis of a new model of cancer spreading. Currently, both hypotheses are widely studied, however, the second one faces greater challenges given its clinical nature. In 1889, Stephen Paget stated the 'seed and soil' hypothesis in order to elucidate the formation of metastases in certain organs, e.g. breast and prostate cancer often metastasizing in bone, establishing that tumor cells (seeds) from a primary tumor have a preference for specific organs (soil) concluding that metastases form only when the seed and soil are compatible. ${ }^{[14]}$ This phenomenon is also known as metastatic organotropism. Accordingly, the metastatic cascade mainly comprises the physical translocation of a cancer cell from the primary tumor to the microenvironment of a distant tissue having as end-stage its colonization. This process consists in a series of complex steps, which must be successfully completed, involving (Figure 1):

b) angiogenesis, forming new blood vessels,

c) intravasation, where tumor cells detach and leave the primary tumor via the bloodstream or the lymphatic system,

d) tumor cells survival in the bloodstream and arrest in capillaries of distant organs,

e) extravasation of tumor cells, and

f) colonization and formation of a secondary tumor still in interaction with the primary one and capable to create a new microenvironment favouring proliferation 


\section{WILEY-VCH}

At early stages of tumor formation, neoplastic cells are supplied with nutrients and oxygen by simple diffusion. When the tumor reaches a specific size, 1-2 mm, vascularization is needed for the tumor to grow. In fact, angiogenesis is a prerequisite for massive tumor growth and metastatic progression. ${ }^{[16]}$ This neo-vasculature can also provide an escape route from which cells can leave the tumor and enter into the body's circulatory blood system. Tumor cells must first detach from the primary tumor and invade towards blood vessels, penetrating the basement membrane and the endothelium, and finally disseminating through the blood vessel. Cancer invasion is initiated and maintained by signaling pathways that control cytoskeletal dynamics in tumor cells and regulate the mechanism of cell adhesion (cell-matrix and cell-cell). This suggests the microenvironment plays a significant role in determining cancer cell migration. ${ }^{[17,18]}$ Depending on the tumor environment, cancer cell migration can occur individually, when cell-cell junctions are absent, or collectively as multicellular groups, when cell-cell adhesions are retained. Cancer invasion is not always the result of an active cell migration. When the surrounding tissue does not hinder the expansion of the tumor, the expansive growth may displace cells by volume expansion and pushing, this phenomenon accounting for a passive migration model. ${ }^{[17]}$ On the other hand, the process of cancer cell individualization and acquisition of an invasive migratory phenotype is associated with the activation of the epithelial-to-mesenchymal transition (EMT) program, which allows an active migration of cancer cells. ${ }^{[19]}$ It has been observed that invading cells often display characteristic EMT markers, such as downregulation of E-cadherin and upregulation of Vimentin expression, while losing some epithelial characteristics, such as polarity. ${ }^{[20]}$ However, the downregulation of E-cadherin expression is likely tunable as evidenced by the identification of hybrid phenotypes, suggesting that cells could undergo a partial EMT process during migration. ${ }^{[21]}$ Tumor cells transitioning between epithelial and mesenchymal phenotypes, (i.e., partial EMT) have mixed epithelial (e.g., adhesion) and mesenchymal (e.g., migration) properties, thereby 


\section{WILEY-VCH}

allowing them to move collectively as clusters. ${ }^{[22]}$ More recently, a cooperative model has also been proposed in which EMT and non-EMT cells cooperate to complete the migration process and subsequent metastasis. ${ }^{[19,23]}$

Migratory cells that detached from the primary tumor and successfully intravasate into blood vessels are likely to follow the hematogenous route for spreading through the body. Although the circulatory system is frequently considered as the major route for cancer dissemination, evidence suggests that the lymphatic system also plays a role in it. ${ }^{[24]}$ Gaining access to the circulatory system provide tumor cells, also known as CTCs in this stage of cancer spreading, direct access to virtually all organs of the body. The amount of cells released by the tumor and entering the blood circulation is estimated to be in the range of millions, 3 to 4 millions of cells/day per gram of primary tumor in murine models, ${ }^{[25]}$ but just a few will survive within the bloodstream. Once into the blood circulation, major CTC death occurs due to anoikis, a programmed cell death that occurs when they detach from the extracellular matrix. ${ }^{[26]}$ CTCs are also directly exposed to the innate immune system and most of them are cleared by natural killer (NK) cells through immune-cell-mediated lysis. Nevertheless, a small subpopulation of CTCs might evade or survive encounters with immune cells by means of diverse mechanisms. ${ }^{[27]}$ Additionally, CTCs must survive the effects of fluid shear within the blood flow in order to contribute to metastatic seeding. Based on these observations, we can infer that the persistence of CTCs in blood circulation is limited. Its half-life has been estimated to be in the range of $1-2.4 \mathrm{~h}$, in breast cancer patients. ${ }^{[28]}$

Cancer cells in blood circulation will disseminate following blood-flow patterns. In fact, in 1920, James Ewing challenged the 'seed and soil' hypothesis suggesting that circulatory patterns between a primary tumor and determined secondary organs were sufficient to initiate organ-specific metastasis. ${ }^{[29]}$ Both hypotheses are not mutually exclusive but rather complementary, and it is believed that both contribute to the formation of site-specific 


\section{WILEY-VCH}

metastasis, as evidenced by various autopsy studies and murine in vivo models. ${ }^{[30-33]}$ Thus, routing dictated by the innate blood circulation and the local microenvironment of the host organ determine the formation of a secondary tumor.

CTCs usually get trapped in the first (or second) capillary bed they encounter during their first pass through the heart, this due to size restriction since they are generally 2 to 4 -fold larger in diameter than capillaries $(\sim 8-\mu \mathrm{m}$ diameter) (Figure 2,A). Other physical factors such as hemodynamic forces and deformability of the cancer cell will determine their arresting in the microvasculature. ${ }^{[34]}$ It is thought that physical trapping within capillaries is one of the mechanisms exploited by tumor cells for extravasation. However, CTCs can undergo adhesive lodging in pre-capillary vessels (venules) that are larger than the cancer cell, via adhesion molecules which facilitate direct interaction with the endothelium (Figure 2,B). ${ }^{[33,35,36]}$ Only those cells that find a stable adhesion and chemoattractive gradient arising from a particular tissue will extravasate into a new site.

Infiltrated cancer cells may invade the local extracellular matrix and colonize the targeted distant tissue. In addition, CTCs can also re-infiltrate their primary tumors of origin (selfseeding) and affect tumor progression. ${ }^{[37]}$ Molecular interactions between the local microenvironment and the extravasated CTCs, also known as disseminated tumor cells (DTCs), are critical and will determine DTCs survival and adaptation. This stage of the metastatic cascade is considered to be the less efficient, only a small subset $(<0.01 \%)$ of infiltrated cancer cells is able to initiate cell division and proliferate, ${ }^{[38]}$ and the vast majority will undergo apoptosis within 24 hours of extravasation. ${ }^{[39,40]}$ Accordingly, cells that survive to the new microenvironment will form micrometastases and an even smaller portion of them will continue their growth to form macroscopic metastases (Figure 2E-F). This suggests that only a subset of CTCs has a metastasis-initiating capacity. ${ }^{[41,42]}$ It is thought that CTCs with an epithelial-like phenotype are more suitable for colonization implying that metastases might arise from CTCs 


\section{WILEY-VCH}

with preserved epithelial characteristics or from cells having undergone EMT, and upon reaching a secondary organ undergo the reverse process (mesenchymalto-epithelial transition or MET). Moreover, infiltrated CTCs can adopt a dormancy state, meaning that viable DTCs may persist and survive within the host tissue for long periods of time in a quiescentnonproliferative state (Figure 2, D). The mechanisms governing this quiescent state remain elusive and are the subject of intense investigation. ${ }^{[43,44]}$ In line with this idea, the parallelprogression model of cancer metastasis is reinforced proposing that early dissemination of cancer cells from the primary tumor may occur and may undergo parallel progression. ${ }^{[2]}$ To add an additional layer of complexity, it was recently suggested that distant tissue microenvironment could undertake a series of molecular and cellular changes to form a premetastatic niche before the arrival of tumor cells, and subsequently, facilitate tumor cell colonization and promote metastasis. ${ }^{[45]}$ This phenomenon could be driven by the interplay among primary tumor-derived factors, tumor-mobilized bone marrow-derived cells, and local stromal components. ${ }^{[46]}$ As here discussed, the fate of metastasis relies on the translocation of tumor cells and their colonization in a distant host environment. From a therapeutic standpoint, understanding the mechanisms of physical translocation would provide insights and new therapeutic strategies for preventing metastasis in patients who are diagnosed with early cancer lesions. The comprehension of mechanisms leading to a successful colonization could lead to more effective therapies in patients with already-established metastases. Therefore, the successful translation of new research findings into clinical routine depends, among many other things, on the sampling of clinically accessible biological targets.

\section{Liquid biopsy: blood-based cancer biomarkers}

Liquid biopsy has become recognized as a novel source of cancer biomarkers (Figure 3), and these blood-based signatures can be addressed by analyzing tumor-derived materials such as 


\section{WILEY-VCH}

CTCs, cell-free fragments of nucleic acids (DNA, mRNA, miRNA, and lncRNAs), proteins, peptides, or extracellular vesicles. More recently, tumor-educated platelets have also been reported as another source of tumor signature in blood. ${ }^{[47]}$ Among the vast range of tumorderived material in the bloodstream, circulating tumor cells, circulating free DNA (cfDNA), and extracellular vesicles dominate the research field of liquid biopsy. Historically, the presence of epithelial cells in blood was first documented by Thomas Ashworth in 1869. Nonetheless, the detection of epithelial cancer cells hidden among hematopoietic cells was intensively investigated and recognized in bone marrow during the 90 's in the field of minimal residual disease (MRD) monitoring. ${ }^{[48,49]}$ Following those findings, researchers focused on peripheral blood as an easier access to cancer epithelial cells, later named CTCs. ${ }^{[50-53]}$ Along this line, the presence of fragments of cell-free DNA in human blood was first described in 1948 by Mandel and Métais, but it was until 1989 that Stroun reported at least some cfDNA in the plasma of patients with cancer originates from cancer cells. ${ }^{[54]}$ A few years later, the term circulating tumor DNA (ctDNA) was introduced when it was formally confirmed that mutant DNA fragments in plasma were of tumor origin. ${ }^{[55]}$ The relative ease of isolating cell-free DNA from plasma samples and the advent of digital PCR and next-generation sequencing-based technologies have spurred research activity in this field. ${ }^{[56]}$ In the last decade, tumor-secreted extracellular vesicles have emerged as a source of intracellular components such as proteins and RNA. ${ }^{[57,58]}$ Hereafter, a broad introduction of these categories of blood-based biomarkers will be provided, with a particular emphasis on the field of CTCs, since this biomarker is the main subject of this review.

\subsection{Circulating tumor DNA (ctDNA)}

Cell-free DNA is continuously released in fragments into the blood circulation through processes such as apoptosis and necrosis, and possibly also active secretion, by both normal 


\section{WILEY-VCH}

and cancerous cells (Figure 4). ${ }^{[56]}$ Circulating free DNA (cfDNA) has a half-life in the circulation ranging from 16 minutes to 2.5 hours and a characteristic length in integer multiples of 180-200 base pairs. ${ }^{[56,59]}$ On the other hand, circulating tumor DNA (ctDNA) only represents a small fraction $(<1 \%)$ of total cfDNA and these molecules are shorter than non-mutant cfDNA $(134-144 \mathrm{bp}) .{ }^{[56]}$ Thus, the size of DNA fragments is one of the accessible parameters to discriminate between tumor-derived and non-tumor DNA, but still, the biology behind cfDNA fragmentation is unclear. ${ }^{[60]}$ However, longer fragments of cfDNA could potentially provide complementary information.

As a cancer biomarker, ctDNA is attractive due to the ease with which plasma can be collected and analyzed using a simple workflow. However, its analysis requires highly sensitive techniques such as conventional PCR-based assays and more advanced technologies as targeted/whole-genome sequencing, since tumor-specific mutations can represent as low as $0.01 \%$ of the total cfDNA. ${ }^{[61]}$ These assays provide information about cfDNA levels or genomic signatures such as point mutations, copy number alterations, and methylation changes (Figure 4). The quantitative information obtained allows for the assessment of molecular heterogeneity, monitoring of tumor dynamics, identification of genetic determinants for therapy, tracking of genomic evolution and development of acquired resistance. ${ }^{[56,59]}$ A hallmark of ctDNA analyses is its high degree of specificity as mutations found in cfDNA are in essence unique signatures of cancer. In terms of sensitivity, ctDNA levels are high enough to be detected in most patients with advanced cancer. However, its extrapolation towards early-stage disease and minimal residual disease remains elusive.

\subsection{Extracellular vesicles (EVs): Exosomes}

Tumor-secreted extracellular vesicles (EVs) mainly comprise microvesicles and exosomes, and those are recognized as critical mediators of intercellular communication between tumor cells 


\section{WILEY-VCH}

and stromal cells in local and distant microenvironments. Moreover, they are also implicated in cell-cell communication between cancer cells. Thereby, tumor-secreted vesicles are thought to participate in multiple steps during cancer invasion and perhaps contribute to early steps involved in metastasis. ${ }^{[58]}$ Emerging evidence suggests that EVs, particularly exosomes, derived from cancer cells along with the molecular information they contain can be used as cancer biomarkers. Exosomes are small, $30-150 \mathrm{~nm}$ in diameter, membranous vesicles that contain multiple molecules inside, such as nucleic acids (DNA, mRNA, miRNA, and IncRNAs), proteins (receptors, transcription factors, enzymes, extracellular matrix proteins), and lipids. A representation of the tumor transcriptome can be addressed by analyzing exosomal nucleic acids. Particularly, exosomal miRNAs have been the subject of growing attention as a potential cancer biomarker for diagnosis and monitoring of therapeutic efficiency due to its stability. ${ }^{[57,62]} \mathrm{A}$ limiting factor to establish the routine application of exosomes as cancer biomarkers has been limited by fundamental technical and methodological challenges relying on their small size and the extensive sample preparation required prior to analysis. ${ }^{[63]}$ Nevertheless, given their rich molecular content, exosomes could provide a complementary proteomic and genetic profile of the cell of origin, a trait that cfDNA cannot achieve by itself.

\subsection{Circulating tumor cells (CTCs)}

\subsubsection{Intravascular transit of CTCs}

As previously stated, tumor cells can reach the systemic circulation, $\sim 4$ million of cells/day per gram of primary tumor, ${ }^{[25]}$ as individual cells or as clusters, and clear from circulation within a couple of hours. ${ }^{[28]}$ These epithelial cells exposed to non-adherent conditions are more likely to undergo anoikis, a form of apoptosis. However, tumor cells with an increased malignant potential could develop anoikis resistance through diverse mechanisms, these features being mainly acquired during tumor development and cell invasion in the primary tumor. ${ }^{[26]}$ In 


\section{WILEY-VCH}

addition to the developed anoikis resistance, other threats present in the blood environment must be overcome by CTCs, which include evading the immune system and withstanding the hemodynamic forces. The survival of the rarely found CTCs in the blood circulation mainly depends on the favorable interactions these might have with the abundant background of normal blood cells. This interplay mainly takes place with leukocytes and platelets, cells related to the immune surveillance and coagulation respectively, and, together, represent approximately $1 \%$ of the total blood cell population. Certainly, a direct cell-cell interaction with blood cells is unavoidable and only cancer cells adapted to the circulatory environment may survive.

In order to escape immune surveillance, tumor cells can shed the presentation of ligands involved in their recognition and interrogation by immune system cells, mainly natural killer (NK) cells and cytotoxic T lymphocytes, this representing an advantage to circumvent their elimination. NK cells are well-renowned in controlling the growth of cancer cells at the tissue level. However, their role in preventing metastatic spread has not been clearly demonstrated yet, although recent evidence suggests the necessity of direct cell-cell contact for the elimination of CTCs. ${ }^{[27,64]}$ Recently, studies have also suggested the direct adherence of CTCs on top of neutrophils indicating that CTCs could potentially use immune cells as a bridge to facilitate extravasation, ${ }^{[65,66]}$ as well as the presence of circulating giant macrophages capable of binding CTCs in peripheral blood indicating that CTCs interact with almost all leukocytes. ${ }^{[67]}$ In line with these observations, platelets, the second most abundant population of blood cells, have been shown to actively interact with cancer cells contributing to the haematogenous spread of cancer during invasion, translocation, and extravasation. ${ }^{[68]}$ Early studies evidenced a relation between blood coagulation and cancer disease, since thrombosis is a frequent complication of cancer and it is the second most common cause of death in cancer patients. ${ }^{[69]}$ The association between platelets and CTCs during translocation, known as tumor cell-induced platelet aggregation, confers several advantages to the immunoevasion. It has been reported that the aggregation/adhesion of platelets around tumor cells may form a protective 'cloak' that could 


\section{WILEY-VCH}

shield CTCs from natural killer cell-mediated cytotoxicity and TNF- $\alpha$ mediated cytolysis. ${ }^{[70,71]}$

Adherent platelets may also protect cancer cells from hemodynamic shear stress exerted by blood flow. Moreover, platelet aggregation may also contribute to the activation of EMT program on CTCs and aid the extravasation of CTCs by enhancing their adhesion to the endothelium. ${ }^{[72,73]}$ In addition to the physicochemical interactions between blood cells and CTCs, cancer cells undergo shear stress mainly generated from blood flow but also from collisions between CTCs, blood cells, and endothelial cells lining the vessel wall. ${ }^{[74]}$ It has been hypothesized that hemodynamic shear stress in human circulation $(5-40 \mathrm{~Pa}$ in venous circulation, 40-300 $\mathrm{Pa}$ in arterial circulation) could affect cancer cell survival within the bloodstream inducing significant membrane and cytoskeletal changes and triggering apoptosis. Indeed, in accordance with this hypothesis, it has recently been shown that cancer cell lines with higher metastatic potential are more resistant to shear stress. ${ }^{[75-77]}$ However, it remains unclear whether hemodynamic shear stress can modulate the biophysical properties and functions of CTCs and confer them a metastasis-initiating capacity. As here reviewed, blood circulation is an aggressive environment for foreign tumor cells. Besides the aforementioned survival mechanisms, the survival of tumor cells disseminated through the blood circulation might be enhanced when cancer cells translocate as clusters, also called tumor microemboli. Clusters are rare in the circulation, $2-5 \%$ of the total circulating cancer-associated cells population in comparison with single CTCs, ${ }^{[78,79]}$ and it is thought that they arise from the solid tumor and not from intravascular aggregation events. ${ }^{[80]}$ The number of cells within clusters, in cancer patients, varies from two to over 100 cells where the majority of them exist as small 24 cell-aggregates. ${ }^{[81,82]}$ CTC clusters depict increased anoikis resistance due to a combination of mesenchymal properties, as compared to single CTCs, and persistent epithelial cell-cell junctions. ${ }^{[83]}$ Further, the cooperation between cells within CTC clusters may confer resistance to hemodynamic forces within the circulation. In addition to its capacity to survive in the 


\section{WILEY-VCH}

bloodstream, CTC clusters are also suggested to have an increased metastatic potential. ${ }^{[78]}$

\subsubsection{Biophysical differences of CTCs and blood cells}

The presence of cancer cells in the blood of metastatic patients has been quantified since the early 50's evidencing its low frequency, i.e. one cancer cell among $10^{5}-10^{6}$ peripheral blood mononuclear cells. ${ }^{[84,85]}$ Their identification by microscopic pathological analysis indicated that CTCs preserve the cytomorphologic features of tumor cells in tissue, characterized by a high nuclear-to-cytoplasm ratio, and irregular size and shape, when compared to normal epithelial cells. Cancer cells are frequently found having extremely large nuclei and being multinucleated, as a sign of abnormal division. ${ }^{[86]}$ It is worth noting that CTCs exhibit a high degree of pleomorphism, cell variations in size and shape, similar to those observed in primary and metastatic tumor tissue. ${ }^{[79,87,88]}$ Given those characteristics, cancer cells are normally larger than normal blood cells. Indeed, S. H. Seal, a pioneer in the field of CTCs, was the first suggesting that cancer cells are generally, but not always, larger than normal cellular blood elements and also more rigid. ${ }^{[89]}$ However, the presence of a population of small CTCs should not be ignored. It is generally accepted that the vast majority of tumor cells, but not all, have distinct biophysical properties compared to normal blood cells. In terms of size, CTCs range from $<4$ to $>30 \mu \mathrm{m}$ in diameter, ${ }^{[90]}$ and this dimension varies depending on the tissue of origin as well as among patients. When compared to blood cells, CTCs' diameter is usually larger than that of erythrocytes and platelets, and it mostly overlaps with the diameter of leukocytes. Additionally, and in line with reported observations, CTCs' volume is on average at least 2-fold the one of leukocytes.

Cancer cell deformability has also been investigated since this property is associated with invasive and migratory phenotypes. Deformability, rigidity and motility measurements using various techniques, evidenced that malignant cancer cells are often more deformable than non- 


\section{WILEY-VCH}

malignant cells, the latter related to their mesenchymal phenotype. ${ }^{[91-94]}$ However, the majority of these biomechanical measurements have been performed on patient tumor cells under adhesion conditions which may change the cytoskeletal properties, a determinant factor of cellular mechanics, and measurements do not necessarily reflect the properties of CTCs in blood circulation. More recently, the mechanical properties of suspended cancer cells prior and after exposure to fluid shear stress were measured, indicating that transformed cancer cells adapt to the magnitude of the stress by increasing their rigidity. ${ }^{[95]}$ This is in agreement with results obtained by computational modeling, where it is suggested that a CTC with a stiff cell cortex should better survive during its passive transport in the blood flow. Interestingly, the model showed that dynamic changes in the stiffness of the cytoskeleton during intravenous transport are required for successful adherence to the endothelium. ${ }^{[96]}$ Based on the aforementioned, a high degree of cytoskeletal deformability seems to be a predominant trait of malignant cancer cells at the tumor level since it may confer to cancer cells the ability to invade surrounding tissue and gain vascular access, while a more solid-like cytoskeleton may be able to develop the required internal stresses to counteract hematological forces and resist lethal deformations. ${ }^{[97]}$ Nevertheless, relating these insights derived from the biophysical characterization of stiffness/deformability of cultured cancer cells back to the metastatic processes that occur in vivo remain at the level of speculation. Regarding CTC and blood cell differences in deformability, the fact that a significant fraction of CTCs is physically retained in the microvasculature is perhaps the clearest evidence that cancer cells have stiffer mechanical characteristics in comparison with normal blood cells. This increased stiffness could be related to the higher nuclear-to-cytoplasm ratio of cancer cells which confers them a greater resistance to deformation, knowing that the nucleus is the stiffer organite of the cell. Some efforts have been made to directly compare the intrinsic cell deformability of tissue tumor cells and leukocytes, finding that cancer cells are significantly stiffer, ${ }^{[98,99]}$ but the transposition to 


\section{WILEY-VCH}

patient-derived CTCs is still uncertain. In this context, the deformability of CTCs versus blood cells in suspension has been recently explored by Bagnall et al., confirming that tumor cells and CTCs could be less deformable than blood cells. ${ }^{[100]}$ However, we cannot exclude that a small part of CTCs in circulation may be as deformable as blood cells.

\subsubsection{Membrane surface markers of CTCs}

In terms of biochemical properties, CTCs also differ from blood and normal epithelial cells. Most of the scientific research has focused on this field, given that the identification of specific biochemical signatures driving their altered behavior could be used as therapeutic targets to treat or reverse the malignant disease. The alterations in the cell surface membrane of cancer cells are believed to be the result of changes in their genome. Most of tumor-associated markers are proteins. However, patterns of gene expression are also considered as tumor markers but these are cancer-type dependent. ${ }^{[101]}$ Vast efforts have targeted the accessible cell-surface receptors at the membrane level, since this is the main structure through which cells communicate and interact with other cells and their microenvironment. The extracellular molecules of cancer cells may range from cell adhesion molecules, cytokines/growth factors, hormone receptors, and neurotransmitters receptors. At the cell level, the identification of cell surface markers, also known as surface antigens, has been used to classify CTCs according to the expression-level of specific molecules. The three most accepted families of antigen signatures that may be present alone or in different combination on CTCs are the epithelial, mesenchymal and stem-like markers. ${ }^{[102]}$ However, variations of diverse extracellular molecules can also be found depending on the cancer type, the stage of the disease, and the disease progression during treatment. ${ }^{[103]}$ Additionally, non-cancerous conditions can also cause the overexpression of these molecules. Due to the epithelial nature of carcinomas, some 


\section{WILEY-VCH}

CTCs could express the Epithelial Cell Adhesion Molecule (EpCAM), a cell surface glycoprotein normally found in neoplastic epithelial cells and at lower levels in normal epithelia. ${ }^{[104,105]}$ However, the downregulation of EpCAM commonly occurs during the epithelial-to-mesenchymal transition which is a process widely associated with the enhanced ability of cells to enter the blood circulation, survive within the bloodstream, and develop treatment resistance. ${ }^{[19-21,106,107]}$ Additionally, cancer of non-epithelial origin such as melanoma and glioblastoma do not express this molecule. Along with EpCAM, other epithelial markers could also be expressed, such as E-cadherin, Cytokeratin (CK), and Zonula Occludens (ZO). ${ }^{[107]}$ Epithelial carcinoma cells can be transformed into a higher mesenchymal state, and during this process hybrid phenotypes can be present. ${ }^{[21]}$ For this reason, it is difficult to find CTCs having a pure mesenchymal phenotype. EpCAM could still be expressed on those hybrid phenotypes but it is dependent on the EMT stage and when downregulated, it can be coexpressed together with mesenchymal markers such as $\mathrm{N}$-cadherin, Vimentin, ZEB1, and Twist1, just to mention a few. ${ }^{[107]}$ EpCAM could finally disappear in the same manner as Ecadherin. Among the whole CTC population, it has been suggested that only a specific subpopulation may have the ability to self-renew and differentiate in order to create new tumors at distant sites from the primary one. ${ }^{[108]}$ In this context, Cancer Stem Cells (CSC) possess all of these fundamental requisites for cancer cell invasion and metastasis, thus there is special interest in detecting this CTC subpopulation. The CTC population identified as CSC has usually mixed epithelial, mesenchymal and stemness properties and the diversity of surface markers can be increased according to the organ/tissue of origin. Apart from epithelial and/or mesenchymal markers, specific molecular signatures of CSC have been suggested to identify this population of cells. For example, CD44, CD24 and Aldehyde dehydrogenase-1 (ALDH1)

surface antigens have been used to identity CSC in breast cancer. ${ }^{[109]}$ However, stemness 


\section{WILEY-VCH}

markers on CTCs are still under deep investigation and discussion.

Taken together, these findings evidence that our knowledge of the biophysical, biochemical and behavioral characteristics of CTCs is in contrast with our understanding of the normal constituents of the peripheral blood. More in-depth studies using a variety of platforms and patient-derived CTCs are necessary to fully reveal their properties, since CTCs provide the unique opportunity to study the whole cell, allowing DNA, RNA and protein-based molecular profiling, which can be used as cancer biomarkers but also to identify cells with an increased tumor-initiating capacity. However, one of the main challenges concerns the isolation of such abnormal cell type from the vast blood cell population and, perhaps with the same level of importance, keeping them alive to perform systematic and precise proteomic and functional characterization. Along this line, an overview of the technological efforts (Table 1) that have been recently developed to face the challenges of their isolation, identification, and characterization. Those technologies evidence a wide diversity in the population of CTCs, accordingly to the tissue of origin.

\section{Methods and technologies for CTC separation from blood samples}

Currently, CTCs must be first isolated prior to any phenotypic or genotypic analysis to confirm their nature. The separation of extremely rare CTCs from blood samples is the initial step of the non-standardized CTC workflow and the advent of techniques and processes to achieve it has been driven by the relatively easy access to blood samples directly from cancer patients. The guidelines for phlebotomy, drawing or removing blood from the circulatory system, allow the frequent access to specific volumes of blood. These samples are collected in 2-10 mL sterile tubes, which preserve the specimen for a determined period of time. Thus, CTC separation processes used in clinical and research laboratories fit into the conventional volumes. Cell separation has been widely used in clinics and research laboratories for the analysis of 


\section{WILEY-VCH}

heterogeneous cell populations such as immune cells from the peripheral blood. The basic principle of separating CTCs from blood cells is to utilize one or more properties, biochemical or biophysical, that are unique to this cell type. Two main groups are commonly proposed to classify the technologies dedicated to the separation of CTCs. Those platforms taking advantage of the cell surface markers of cancer cells are classified under the immunoaffinity category. The others benefit from the biophysical differences of CTCs with respect to blood cells and fall under the biophysical category. Additionally, cell separation can also be classified as positive and negative selection. Positive selection aims at isolating the target cell type (i.e., CTC) from the entire population (i.e., blood cells) while a negative one is an indirect method for CTC separation based on the depletion of the unwanted cell types. Some platforms also combine both positive and negative selection approaches to reduce the background of blood cells and improve the purity of separated cells. Extensive reviews on technologies available for the isolation and identification of CTCs have been published. ${ }^{[18]}$ Hereafter some of the current and most employed methods (commercially available) for CTC enrichment are briefly presented.

\subsection{Immunoaffinity-based technologies}

Immunoaffinity-based separation strategy, or immunocapture, is the most widely used approach for the isolation of CTCs from blood samples. This method uses engineered antibodies directed against antigens expressed by the targeted cells. A particular antibody or cocktail of antibodies can be coated onto a surface and be in turn placed directly in contact with the blood sample allowing the antigen-antibody interaction. This interaction binds the targeted cell to the functionalized surface and enables cell separation. It is important to emphasize that there is currently no CTC-specific antigen, which renders their separation from blood cells challenging. When a positive selection of CTCs is performed, the antibodies against cancer cells are typically bound to the functionalized surface of either magnetic micro/nano beads or specific devices. As 


\section{WILEY-VCH}

previously introduced, EpCAM antigen is found to be expressed in cancer cells of epithelial origin and not in normal blood cells. Thus, this antigen is widely used as target for affinitybased CTC enrichment, keeping in mind that no CTC-specific antigen has been evidenced up to now. Conversely, when a negative selection is aimed, the cell surface marker commonly targeted is the CD45 antigen expressed in WBCs. This method is usually preferred when no bias from selection markers is desired.

Cell separation platforms based on the magnetic principle pre-mix blood samples with antibodycoated magnetic beads and subsequently expose them to a controllable magnetic field. This magnetic field acts as a filter. The magnetic beads carry the targeted cells towards the magnets where they are retained, while unlabelled cells flow through or are washed out. Based on ferrofluid nanoparticles coated with anti-EpCAM antibody, the CellSearch System (Menarini Silicon Biosystems) is the first and only clinically validated blood test cleared by the U.S. Food and Drug Administration (FDA) for detecting and enumerating CTCs. CTCs are magnetically separated from centrifugated blood samples in a fully-automated system, which can also perform their recognition. Currently, this system is considered as the gold standard within the field, since emerging technologies for CTC isolation are usually compared to this system. In a similar fashion, AdnaTest (Adnagen AG) uses antibody-coated magnetic beads but rather than using a single antibody uses a cocktail of antibodies specific to a given cancer type. Additionally, this assay allows the evaluation of gene expression on isolated cells. Other available technologies based on magnetic separation from clinically acceptable blood volumes are the Magnetic-Activated Cell Sorting (MACS, Miltenyi Biotec) and MagSweeper platforms. ${ }^{[119]}$ With the technological advances in microfluidics, which allows the precise control of fluids, several platforms have been developed, combining micro-scale channels with magnetic array-patterns for CTC capture. Some examples are the commercially available 


\section{WILEY-VCH}

LiquidBiopsy Platform (LungLife AI) and IsoFlux (Fluxion Biosciences) platforms which offer fully-automated magnetic-based CTC isolation. Some other examples are the Ephesia chip, ${ }^{[120]}$ and the Magnetic Sifter fluidic platforms. ${ }^{[121]}$ In this field, a vast range of microfluidic-based platforms have also been proposed using integrated micro- and nanopatterned surfaces decorated with antibodies. As a hallmark, microfluidic devices would allow the precise control of the flow which increases the likelihood of cell-antibody interactions, and consequently enhanced CTC capture. The first platform using this approach was the CTC-Chip which integrates an array of anti-EpCAM coated microposts along the flow path ${ }^{\left[{ }^{[22]}\right.}$ Following the same idea, other microfluidic platforms have used antibody cocktails to enhance cell capture, such as OncoCEE (Biocept). Some other platforms, such as the Herringbone-Chip (HBChip), ${ }^{[10]}$ the Geometrically Enhanced Mixing (GEM) chip, ${ }^{[123]}$ and the Geometrically Enhanced Differential Immunocapture (GEDI) platform, ${ }^{[124]}$ have focused on enhancing interactions and contact frequency between the cell and the antibody-coated surface. Complementary to microfluidic platforms and with the use of nanopatterning techniques, some research groups have also taken advantage of the local topographic interactions between cancer cells and a diversity of anti-EpCAM coated nanostructured substrates to improve the capture efficiency and purity of CTCs. ${ }^{[125]}$

\subsection{Technologies based on physical properties of CTCs}

Some isolation platforms have taken advantage of the common features observed on CTCs, such as density, size, deformability and electric charge to separate them from normal blood cells. Those antibody-free methods are hereafter sub-classified.

\subsubsection{Centrifugation}




\section{WILEY-VCH}

The fractionation of whole blood using density-based gradient centrifugation has been used for almost 100 years to separate CTCs from the background of blood cells, ${ }^{[126]}$ and remains a simple and inexpensive method. Centrifugation of whole blood results in the fractionation of cells in three layers, where plasma and RBCs are on the top and bottom layer respectively, and a mixture of WBCs, platelets, and CTCs is located at the middle layer. Although it was not originally designed for the isolation of CTCs, early studies reported the use of Ficoll-Paque (GE Healthcare) density gradient media to improve the fractionation of blood. More recently, OncoQuick (Greiner Bio-One) developed a specialized separation tube to allow a further depletion of erythrocytes, granulocytes, lymphocytes and mononuclear cells towards the bottom layer. RosetteSep ${ }^{\mathrm{TM}}$ (STEMCELL Technologies), combines centrifugation with immunoaffinity-based enrichment, crosslinking unwanted cells to RBCs to increase the purity of targeted CTCs. Based on the principle of centrifugation as well, Accucyte ${ }^{\circledR}$ (RareCyte) is another available platform for blood fractionation. However, in all these technologies, the fraction corresponding to enriched CTCs still contains platelets and some WBCs sharing similar characteristics to those enriched CTCs. Thus, centrifugation-based platforms are usually a preenrichment step for subsequent specialized CTC-isolation platforms.

\subsubsection{Microfiltration}

Microfiltration of blood has been used since S. H. Seal observed some of the intrinsic properties of cancer cells as being relatively larger than WBCs and less deformable than blood cells. ${ }^{[89]}$ These traits enable flowing blood cells through micrometric-range constrictions designed to retain CTC population only. Using this approach, no functional modifications of the surface are required since cells are trapped by their intrinsic size and deformability. Based on this principle,

ISET ${ }^{\circledR}$ (Rarecells Diagnostics) and ScreenCell ${ }^{\circledR}($ ScreenCell) use track-etched membranes 


\section{WILEY-VCH}

containing $8 \mu \mathrm{m}$-pores randomly placed to isolate CTCs from buffer-diluted blood samples.

One of the limiting factors of this approach is clogging when whole blood is processed, thus high pore density and relatively high driving pressures are needed. To face these limitations, micropatterned membranes based on a photolithographic technique have also been proposed controlling the size, shape/geometry, and distribution of pores on different materials such as Silicon, ${ }^{[127,128]}$ Silicon/Silicon-Nitride (VyCAP microsieve, VyCAP), ${ }^{[129]}$ Nickel, ${ }^{[130]}$ and polymers like SU-8 (CellSieveTM, Creatv MicroTech), ${ }^{[131]}$ and Parylene-C. ${ }^{[132,133]}$ The size of pore ranges from 5 to $12 \mu \mathrm{m}$ having typically circular shapes and a total number of pores in the range of $10^{3}-10^{5}$. Another associated issue related to microfiltration is the mechanical stress on CTCs once they are trapped into the pores, thus limiting their viability. Filtration membranes in a stacked bilayer configuration were presented as a strategy to diminish stress on captured cells. ${ }^{[134,135]}$ In the field of microfluidics, some platforms have proposed the use of arrays of pillars or traps, ${ }^{[136-138]}$ stair-like architectures (Parsortix, ANGLE), and pneumaticallycontrolled isolation gaps integrated within microchannels in order to retain CTCs by size. ${ }^{[139]}$ Similarly, CTC-clusters have the intrinsic characteristic of being larger than individual CTCs. Thus, taking advantage of this biophysical trait, a microfluidic device, Cluster-Chip, was optimized for the isolation of CTC-clusters based on an array of pillars. ${ }^{[81]}$

\subsubsection{Hydrodynamic cell sorting}

Microfluidic channels having specific geometrical dimensions and controlled flow rate generate hydrodynamic forces (inertial forces) that allow sorting cells based on their size. ${ }^{[140]}$ For example, Vortex HT Chip (Vortex Biosciences) uses inertial focusing to position CTCs along the microchannel and then trap them into vortices generated by the sudden expansion of the channel. ${ }^{[141]}$ Similarly, the CTChip ${ }^{\circledR F R}$ (Clearbridge Biomedics) uses spiral microchannels to 


\section{WILEY-VCH}

exploit the centrifugal forces (Dean drag force) in combination with the inertial focusing to separate CTCs from the rest of blood constituents. ${ }^{[142]}$ In this context, some platforms have used deterministic lateral displacement (DLD) to separate large cells from blood samples. This technology uses a specific arrangement of micropillars along the channel to control the trajectory of cells. By controlling parameters such as shape and distance in-between pillars, the separation of small blood cells (RBCs and Platelets) from large ones (WBCs and CTCs) is reached. ${ }^{[143]}$ This strategy has also been used to separate CTC-clusters from blood using a twostage microfluidic platform. ${ }^{[144]}$ The same research group, has combined DLD, inertial focusing and magnetophoresis within the CTC-iChip to isolate CTCs from whole blood samples. ${ }^{[145]}$

\subsubsection{Dielectrophoresis (DEP)}

This approach uses the electrical properties of cells to exert forces on them via an external electric field. Those forces can be repulsive or attractive relative to the position of the electric field source and depend on both the dielectric characteristics of the cells (diameter, membrane, density, conductivity, volume) and their surrounding environment. ApoStream ${ }^{\circledR}($ ApoCell) uses dielectrophoretic forces to attract CTCs near the electric field and repel WBCs in continuous flow. ${ }^{[146]}$ The platform requires centrifugated samples and the adjustment of the suspension medium conductivity. DEPArray ${ }^{\mathrm{TM}}$ (Menarini Silicon Biosystems) is a platform based on repellent forces to manipulate and recover individual cells in an array of electrodes. However, this platform is not dedicated to the isolation of CTCs from whole blood samples, it is rather employed for the identification of cells from pre-concentrated samples.

\section{Methods and technologies for cell identification}

The isolation of CTCs from blood samples using the technologies above-described is the initial step in the CTC-based liquid biopsy workflow. In order to use these cells and the biological 


\section{WILEY-VCH}

information they contain, their interrogation and identification as cancerous cells are required. The conventional methods currently used for CTC identification are based on cytometric and polymerase chain reaction (PCR) techniques. In the early 50's the papanicolaou staining (by George Papanikolaou in 1928) became widespread, allowing the visual assessment and identification of specific proteins on cancer cells and tissue fragments under a fluorescence microscope. At the same time, cytopathology had become a major tool for cancer diagnosis. These protocols were initially applied for the identification and discrimination of CTCs from blood cells. Currently, no standardized detection method exists for CTCs; nonetheless, the cytomorphological analysis combined with immunostaining (immunohistochemistry or immunofluorescence) protocols is the most frequently used strategy since it allows the visual inspection and enumeration of cells. Along this line and given the lack of CTC-specific markers, CTCs have been commonly discriminated from blood cells by the positive expression of the epithelial cell adhesion molecule (EpCAM+), cytokeratins $(\mathrm{CK}+)$ which are intracellular structural proteins found in epithelial cells, and the negative expression of CD45 (CD45-) which is specific to leukocytes and used to discard contamination of blood cells having similar morphology than CTCs. Complementarily, the cell nucleus is stained with DAPI (DAPI+) to exclude cellular fragments and cytomorphological analysis is also carried out. For instance, the FDA-cleared CellSearch platform identifies CTCs among the enriched cells based on the expression of cytokeratin 4-6, 8, 10, 13, 18 and 19, lack of CD45 expression, presence of a nucleus, and a cytomorphology of neoplastic cells with a minimum diameter of $4 \mu \mathrm{m} .^{[128]}$ However, the expression/absence of these markers only allows classifying these cells as rare epithelial cells in whole blood but does not ensure either their tumor-derived origin or malignancy. Since, it has been reported that other rare non-tumor cells with similar antigen expression could also be present in blood circulation due to various pathological conditions such as inflammatory diseases. ${ }^{[147]}$ Despite this, the detection of these EpCAM- and 


\section{WILEY-VCH}

cytokeratin-positive cellular events is known to have prognostic significance in a variety of metastatic cancer types. The expression of these fluorochrome-conjugated antibodies on CTCs is verified by measuring the fluorophore intensity with high-definition (HD) fluorescencebased optical systems such as fluorescence microscopy (static) and flow cytometry (in flow). Using this approach, the associated detection rates are strongly dependent on the technology used to this end. Sample imaging using fluorescence microscopes is a time-consuming step particularly when large areas are required to be inspected. In order to address this point, platforms as CellSearch and DEPArray have incorporated semi-automated fluorescence imaging systems into their workflow. Some other independent technologies such as FASTcell $^{\mathrm{TM}}$ (SRI Biosciences), Epic platform (Epic Sciences), and CytoTrack (CytoTrack) combine HD imaging with computer algorithms for the identification of CTCs. In the same line, ImageStream ${ }^{\circledR}$ (Amnis-Merck) combines conventional flow cytometry with fluorescence imaging to identify CTCs from a background of cells in suspension. Moreover, systems based in flow cytometry, a standard and largely employed procedure, offer a fast method to process samples. However, these systems require a relatively large quantity of cells to sample. Isolated cells are usually further characterized at the molecular level to evaluate their malignancy and tumor-derived nature. Hybridization-based methods using fluorescent probes, such as Fluorescent In Situ Hybridization (FISH) are frequently applied for the visual localization of a specific segment of a nucleic acid in individual cells. Dual color or tricolor fluorescent probes are implemented for the detection of chromosomal abnormalities such as the presence or absence of specific DNA sequences related to the tumor, and this information be used to infer the malignant nature of the isolated cells. For example, this tool has been used to determine whether CTCs express the same genomic changes as the primary tumor. ${ }^{[49]}$ FISH assay detects already established and validated biomarkers such as Anaplastic Lymphoma Kinase (ALK) rearrangements in specific known cancerous tumors, and its implementation on CTCs could 


\section{WILEY-VCH}

potentially guide prognosistics and therapeutic manangment in patients. Along this line, RNAin Situ Hybridization (RNA-ISH) has also been used to confirm the differential expression in epithelial versus mesenchymal phenotypes, confirming CTC heterogeneity. ${ }^{[82]}$ Complementary to hybridization-based methods, padlock probes have also been used to analyze the genetic material of CTCs. ${ }^{[148]}$ The probes are converted into circular molecules upon hybridization to the complementary target sequence. Then after, the circularized padlock probes can be amplified by rolling circle amplification (RCA) in situ. Finally, the amplified products are targeted by fluorophores resulting in bright quantifiable signals. These highly selective and specific padlock probes allow differentiation between sequences differing by only a single base pair, e.g., splice variants and point mutations, providing visual information about clinically relevant molecular markers at the single-cell level. In general, imaging-based techniques allow morphological identification, cell counting, and molecular characterization. However, they are susceptible to false-positive or false-negative results due to the intrinsic biology of CTCs or experimental factors impacting the staining protocols. These techniques require carefulness in setting appropriate signal thresholds with respect to fluorescence intensity making it prone to low specificity and subjective interpretation of the acquired data which can preclude accurate CTC identification. Moreover, immunostanning-based cell enumeration and identification is time-consuming.

Thereby, aside from the visual identification of CTCs by protein expression-based techniques, indirect techniques based on the analysis of nucleic acids have also been used to identify CTCs, in particular PCR-based assays. Following the extraction of nucleic acids by cell lysis, the analysis of mRNA provides real-time information about intracellular activity since they are the direct products of RNA synthesis or transcription. Quantitative reverse transcription polymerase chain reaction (qRT-PCR) has been used to find tumor-associated expression patterns using mRNA strands transcripted into cDNA. This technique has shown to be highly 


\section{WILEY-VCH}

sensitive and specific to quantify specific CTC mutations at the mRNA level. ${ }^{[149-151]}$ However, some protocols used for CTC analysis induce RNA degradation, such as formaldehyde fixation, limiting the isolation of high-quality RNA. ${ }^{[152]}$ Moreover, this type of assays usually analyze the content of many cells and do not provide information concerning which of the molecules detected originate from which cells. It implies having a high purity isolation of CTCs and the implementation of strict positive and negative quality controls. More recently, next-generation sequencing (NGS) enabled massive parallel processing of the whole genome dramatically reducing sequencing time. In this way, a wide gene expression interrogation of patient-derived CTCs is possible even at the single-cell level. ${ }^{[125,153-156]}$ However, single-cell analysis does not provide direct information about CTC counts, morphology and cell heterogeneity. Moreover, in order to study a single CTC, it must first be isolated in a manner that preserves biological integrity using techniques such as laser-capture microdissection (LCM) or flow cytometry. Nonetheless, the selective manipulation of single CTCs remains challenging.

\section{Clinical significance of CTCs: enumeration as a prognostic biomarker}

Several reports have underlined the presence of CTCs in the blood of patients with metastatic disease across all major types of carcinomas, ${ }^{[115]}$ and as here reviewed, they are considered to be the main source of metastases. CTCs are believed to be representative of the tumor, both primary and metastatic sites, and thus, their presence in the bloodstream is associated with an increased risk of disease malignancy. Their isolation, detection, and enumeration based on a determined volume of blood at multiple time points have been set as the acknowledged workflow to offer quantitative information during the evolution of the disease. Enumeration of CTCs has been widely performed using the CellSearch system which has been set as the gold standard for CTC enumeration. Broadly, reports focused on monitoring changes in the number of CTCs in peripheral blood both before and after a new treatment, observing that an increase 


\section{WILEY-VCH}

in the number of CTC counts, over a specific threshold, is associated with cancer progression. In clinical studies, the obtained data has been used as a prognostic biomarker to estimate the overall survival and the progression-free survival using Kaplan-Meier analysis. Both overall survival and progression-free survival measurements provide quantitative information to evaluate the response to treatment. Multicenter studies have proven the prognostic value of CTC counts in metastatic patients (M1) with breast, prostate, and colorectal cancer. ${ }^{[157-159]}$ Results from breast and prostate cancer patients evidenced that levels of circulating tumor cells $\geq 5$ per $7.5 \mathrm{ml}$ of whole blood, as compared with the group with $<5$ circulating tumor cells per $7.5 \mathrm{ml}$, had a shorter median progression-free and shorter overall survival. Based on this criterion, patients are stratified in favorable or unfavorable groups according to levels of CTCs, where 5 CTCs in $7.5 \mathrm{~mL}$ constitutes the cutoff value. Different cutoff values have been established for each carcinoma. For instance, a cutoff value of 3 CTCs in $7.5 \mathrm{~mL}$ has been defined for colorectal cancer. Moreover, these clinical studies correlate the expression of CD45-, EpCAM+, CK 8, 18+ and/or 19+ on CTCs with a more aggressive phenotype and a poor patient outcome. Other studies using small cohorts of patients have also evidenced the prognostic value of CTC counts in non-small cell lung, small-cell lung, ovarian, renal, and melanoma metastatic patients. ${ }^{[160-164]}$ In the clinical prognostic line, complementary clinical studies have focused in non-metastatic cancer patients with early-stage disease, e.g. M0 patients. Those reports have evidenced that CTC detection both before and after adjuvant chemotherapy administrated after primary surgery, is linked to an increased risk of relapse in breast, prostate, colorectal, bladder, and liver cancer. ${ }^{[165-169]}$ However, the very low CTC number and incidence at this stage of the disease raises doubts on whether or not CTC counts are a reliable indicator of an unfavorable prognosis. Moreover, it also suggests that the largest amount of CTCs is more likely to originate from metastatic sites rather than from primary lesions. The use of CTC counts as a predictive biomarker, assessing the likelihood of the disease 


\section{WILEY-VCH}

to respond to a therapeutic intervention, is uncertain and still under investigation. Vast efforts have been accomplished to demonstrate the clinical validity of CTC quantification for monitoring of chemotherapy for breast and castration-resistant prostate metastatic cancers. ${ }^{[170,171]}$ However, some drugs belonging to the targeted therapies family may modify CTC counts impacting the predictive value of CTCs. ${ }^{[172,173]}$ Despite providing valuable information for prognosis, these non-interventional studies have not been able to demonstrate their capacity for therapeutic decision-making yet. Along this line, few interventional trials, also called clinical trials, are currently carried out by different groups, aiming to demonstrate that the use of CTC enumeration and monitoring could drive clinical decisions and improve the clinical outcome of metastatic cancer patients..$^{[174]}$

\section{Current outlook of CTCs in liquid biopsy}

It is evident that remarkable improvements have been made in the detection of early cancer lesions, surgical techniques, and treatment of the primary tumor to improve the outcome of patients with cancer. A major challenge is the treatment and monitoring of patients with already-established metastases which reflects our limited understanding of the biology of cancer in the metastatic setting. As here reviewed, there is an evident clinical need to repeatedly obtain biological information related to both the primary tumor and the metastatic lesion in order to provide more effective therapies to patients. Blood-based cancer biomarkers provide an opportunity to face this need. From the liquid biopsy spectrum, CTCs are the only which can provide disease-related genomic, proteomic, and functional information. The analysis of CTCs goes beyond the biological understanding of the metastatic process, its main goal being to be implemented as a cancer biomarker in clinical routine. From a therapeutic standpoint, in patients with early cancer lesions, it would be a major breakthrough to repeatedly isolate as many CTCs from blood as possible and identify these molecular and functional signatures 


\section{WILEY-VCH}

allowing their physical translocation. Thus, the deep characterization of these cancer cells having metastasis-initiating capacity would provide insights and new therapeutic strategies for preventing metastasis. Similarly, in patients with already-established metastases, the characterization of isolated cells must aim to identify patient-specific therapeutic targets that could lead to more effective therapies.

\subsection{Blood processing: blood collection and sample preparation}

Liquid biopsy, similar to other clinical procedures involving the handling of biological samples such as blood, requires to be processed immediately ( $<24$ hours) or be stabilized with fixatives. Logistics for blood transportation and storage led to the development of dedicated containers

with additives such as anti-coagulants or $\mathrm{pH}$-buffers, in order to avoid platelet aggregation and deterioration of leukocytes. In addition to their rareness, CTCs are subjected to different stress factors during their transit in the human bloodstream, but perhaps to one of a greater impact during blood draw. In fact, relatively high numbers of apoptotic CTCs have been reported in blood samples from peripheral blood, ${ }^{[175,176]}$ evidencing their fragility. It has been reported that cancer cell numbers in blood samples rapidly decline over a time span of 5 hours, revealing that the time from blood draw to cell harvest is critical. ${ }^{[177]}$ Other reports have shown that a significant RNA degradation occurs within a period of 2 to 4 hours. ${ }^{[178-180]}$ These reports highlight the need for an adequate sample preservation for subsequent gene expression profiling. Along this line, diverse strategies have been proposed for the stabilization of CTCs in blood samples such as CellSave tubes (CellSearch System, Menarini Silicon Biosystems), ${ }^{[181-183]}$ the most employed approach allowing up to 96 hours of blood preservation at room temperature conditions. In addition to collection and blood preservation issues, a common trait of CTC isolation platforms is the use of cell fixatives. However, the use of a fixative solution sacrifices cell viability and degrades RNA. ${ }^{[184,185]}$ Another predominant trait of CTC isolation platforms 


\section{WILEY-VCH}

is the requirement of extensive sample preparation, such as RBC lysis, centrifugation, staining, multi-step washing, etc., just to list a few. Thus, those platforms are prone to CTC loss during the isolation process. For instance, in a direct comparison between CellSearch and Flow cytometry platforms, a 3.3-fold loss of CTCs was reported due to the isolation and staining procedures where flow cytometry yielded better results. ${ }^{[186]}$

\subsection{Processing larger volumes of blood}

Intrinsically, low CTC counts are closely related to the amount of blood screened. CTC enumeration from the processing of clinically relevant blood volumes of $7.5 \mathrm{~mL}$, suffers from low statistical power, mainly because this volume represents less than $0.2 \%$ of the total blood volume. Various reports have emphasized the need for a larger volume of blood in combination with high sensitivity assays in order to increase CTC counts and detection rates. ${ }^{[1,186-190]}$ For example, CTC counts in metastatic patients range from one to few tens, reaching up to thousands in very particular cases, and detection rates vary in the interval of $30-80 \%$, depending on the cancer type. These numbers are even lower in non-metastatic cancer. However, the volume of blood taken from the patient cannot be substantially increased. In line with this need, CellCollector (GILUPI Nanomedizin) arose as a technology claiming to access large volumes of blood by placing the detection device intravenously. ${ }^{[191,192]}$ This device is a structured medical guidewire coated with a hydrogel layer which, in turn, is covalently coupled with antibodies against EpCAM. Authors claim that the device is exposed to approximately 1 $\mathrm{L}$ of blood during 30min-residence in the vein. In small patient cohorts, this technology has shown greater numbers of CTCs and in more patients as compared with the CellSearch system. ${ }^{[193-196]}$ Complementarily, an EpCAM-independent strategy, diagnostic leukapheresis, has been recently proposed to increase the volume of blood sampled. This density-based method, processes up to $62 \%$ of the total blood via continuous centrifugation, and collects 


\section{WILEY-VCH}

mononuclear cells with high levels of CTCs. The approach combined with CellSearch technology, revealed a significantly higher detection rate, from $28 \%$ to $72 \%$, in a side-by-side comparison between the $7.5 \mathrm{~mL}$ peripheral blood and the matched $2 \mathrm{~mL}$ diagnostic leukapheresis product. ${ }^{[00,197]}$ More recently, the work by Kim et al. has demonstrated the advantage of placing CTC enrichment systems in aphaeretic conditions for longer periods of time (2h) to substantially increase the number of isolated cells. ${ }^{[198]}$ Alternatively and along the same line, some techniques for in vivo detection/isolation of CTCs and early recruitment of metastatic cells, have also been reported. ${ }^{[199-203]}$ Despite that sophisticated methods have been proposed in the field of microfluidics to increase sensitivity (efficiency $80-100 \%$ ) and selectivity (purity $<70 \%$ ), their intrinsic nature as point-of-care platforms limits the processing of large blood volumes (throughput $\leq 10 \mathrm{~mL} \mathrm{~h} \mathrm{~h}^{-1}$ ). This evidences even more that no single platform is currently capable of detecting more CTCs at higher rates. For this reason, recent studies have combined different CTC-detection platforms aiming to yield clinically useful information. ${ }^{[148,196]}$ Thus, in the perspective of utilizing CTCs in clinical routine, it is clear that beyond CTC enumeration, it will be of utmost importance to harvest more CTCs and to identify those having clinical relevance, in order to complement enumeration data. In addition to the single sampling-point processing of large blood volumes, blood sampling strategies are also required at multiple times and at different venipuncture sites in order to elucidate the actual kinetics of CTC dissemination and phenotypic and molecular changes in the blood of cancer patients. Typically, in clinical settings, blood samples from cancer patients are collected at monthly intervals. However, a recent report based on case studies and hypothetical simulation models, ${ }^{[204]}$ has suggested that weekly, or even more frequent sampling could result in better diagnosis and patient management. 


\section{WILEY-VCH}

\subsection{Isolation of a widely heterogeneous CTC population}

Aside from the biological and medical constraints, the implementation of the CTC-derived data for the therapeutic management of patients in clinical routine is also hindered by technical limitations. Despite the extensive development of technologies for CTC isolation from blood, so far there is no technology or method capable to identify and/or isolate all tumor cell types present in human blood circulation. As here reviewed, many of the CTC isolation methods rely on the detection of cells that express epithelial-related markers in blood. Moreover, most recent clinical trials enumerate CTCs using platforms based on this approach, i.e. CellSearch, targeting the population of cells expressing the cell surface glycoprotein EpCAM. However, it has been extensively postulated that during detachment and dissemination of tumor cells, EpCAM may be downregulated due to the activation of the EMT program, thus some CTCs that either express low levels or completely suppress this antigen are omitted by these methods. Moreover, EMTlike events could occur during the intravascular transit due to EMT inducers secreted by platelets. In general, EpCAM-based isolation systems are an alternative to enumerate tumorderived cells from epithelial cancer types that often express high levels of EpCAM, but they do not ensure detection of the entire pool of CTCs present in the blood circulation. Thus, EpCAM cannot be taken as a universal marker for CTC detection. The transient and variable expression of EpCAM in CTCs points out to a dynamic and heterogeneous population where the mechanisms driving EpCAM and other different molecular expressions are not well understood. This opens up new opportunities for multimarker-based and antigen-independent methods in the pathway of capturing more and a phenotypically wider range of tumor-derived cells. As a consequence, improved identification methods would be required to discriminate between subpopulations, particularly those relevant for patients with either early (i.e., metastasisinitiating phenotype) or metastatic (i.e., drug-resistance phenotype) cancer lesions. 


\subsection{Functional studies on CTCs}

Beyond CTC enumeration from blood samples, there is no strong data demonstrating their clinical utility to drive therapeutic decisions, up to date. The latter is perhaps the main obstacle to their implementation as cancer biomarker in clinical routine. The long-term culture of CTCs and the establishment of CTC lines are the first step enabling the acquisition of qualitative and quantitative information related to the biological activity of CTCs. The data obtained from this type of studies could offer, for instance, the possibility to identify the biological properties of metastatic cells, develop new anticancer drugs, or understand drug resistance mechanisms. In this context, the isolation of viable CTCs is a necessary prerequisite. A platform dedicated to the detection of viable CTCs and subsequent short-term culture of CTCs has been recently introduced, EPISPOT technology, and it is based on the release of CK19 marker from tumor cells. ${ }^{[205]}$ This platform has allowed the establishment of CTC-derived cell lines from blood samples with different cancerous pathologies. ${ }^{[206]}$ Another alternative is the use of in vivo models or xenograft, to create clinically relevant cancer pathologies from CTCs. This technique has also allowed the identification of a subset of CTC population with increased metastatic potential, and the evaluation of anticancer drugs. ${ }^{[41,206]}$ However, the routine implementation of these techniques is currently hampered by the difficulty to systematically and frequently isolate viable CTCs in large numbers, as well as the technical difficulties encountered to culture CTCs.

\section{Conclusion}

If CTCs content and relevance as biomarkers is not questioned, their implementation in clinical routine is hampered by various biological implications and technical bottlenecks. As discussed 


\section{WILEY-VCH}

in this review, the latter include defining the right sampling time, localisation and frequency. They also include isolating a population of CTCs statistically representative of CTC diversity and heterogeneity with minimal bias. This is correlated to the sample volume CTCs should be isolated from to bring statistical confidence to the measure, and to the specificity and sensitivity of the isolation technique to maximize the number of captured CTCs with minimum levels of contamination and with no selection a priori. Other bottlenecks include the isolation of CTCs from fresh unprocessed blood to be able to conduct functional and molecular studies from viable and unaltered material. Overcoming these considerations could unveil many aspects of disease spreading and metastatic processes and could offer a route towards routine analysis of CTCs in clinical practice to guide medical decisions and improve patient care, a step forward towards precision medicine.

\section{Acknowledgements}

The authors gratefully acknowledge financial support from the French National Research Agency (ANR-15-CE19-0020). A. K. Jiménez-Zenteno was partially supported by a doctoral fellowship of the National Council of Science and Technology (CONACYT) of Mexico.

\section{References}

Received: ((will be filled in by the editorial staff))

Revised: ((will be filled in by the editorial staff))

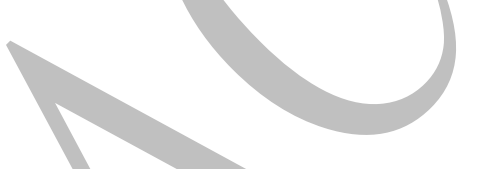

Published online: ((will be filled in by the editorial staff))

[1] M. Gerlinger, A. J. Rowan, S. Horswell, M. Math, J. Larkin, D. Endesfelder, E. Gronroos, P. Martinez, N. Matthews, A. Stewart, et al., N. Engl. J. Med. 2012, 366, 883.

[2] "Welcome to EDRN - EDRN Public Portal," can be found under https://edrn.nci.nih.gov/, n.d.

[3] "GRAIL - Detecting Cancer Early, When It Can Be Cured," can be found under https://grail.com/, n.d.

[4] K. Nakamura, K. Sawada, A. Yoshimura, Y. Kinose, E. Nakatsuka, T. Kimura, Mol. Cancer 2016, 15, 48. 


\section{WILEY-VCH}

[5] A. Di Meo, J. Bartlett, Y. Cheng, M. D. Pasic, G. M. Yousef, Mol. Cancer 2017, 16,

80.

[6] A. Esposito, C. Criscitiello, M. Locatelli, M. Milano, G. Curigliano, Pharmacol. Ther. 2016, 157, 120.

[7] F. R. Balkwill, M. Capasso, T. Hagemann, J Cell Sci 2012, 125, 5591.

[8] A. Klein-Goldberg, S. Maman, I. P. Witz, Cancer Lett. 2014, 352, 54.

[9] J. Cairns, Nature 1975, 255, 197.

[10] P. B. Gupta, S. Mani, J. Yang, K. Hartwell, R. A. Weinberg, Cold Spring Harb. Symp. Quant. Biol. 2005, 70, 291.

[11] S. Hellman, J. Clin. Oncol. 1994, 12, 2229.

[12] C. A. Klein, Nat. Rev. Cancer 2009, 9, 302.

[13] A. D. Rhim, E. T. Mirek, N. M. Aiello, A. Maitra, J. M. Bailey, F. McAllister, M.

Reichert, G. L. Beatty, A. K. Rustgi, R. H. Vonderheide, et al., Cell 2012, 148, 349.

[14] S. Paget, The Lancet 1889, 133, 571.

[15] I. J. Fidler, Nat. Rev. Cancer 2003, 3, 453.

[16] J. Folkman, Cancer Res. 1986, 46, 467.

[17] P. Friedl, S. Alexander, Cell 2011, 147, 992.

[18] A. G. Clark, D. M. Vignjevic, Curr. Opin. Cell Biol. 2015, 36, 13.

[19] L. S. Aroeira, A. Aguilera, J. A. Sánchez-Tomero, M. A. Bajo, G. del Peso, J. A. Jiménez-Heffernan, R. Selgas, M. López-Cabrera, J. Am. Soc. Nephrol. 2007, 18, 2004.

[20] J. J. Christiansen, A. K. Rajasekaran, Cancer Res. 2006, 66, 8319.

[21] M. K. Jolly, M. Boareto, B. Huang, D. Jia, M. Lu, E. Ben-Jacob, J. N. Onuchic, H. Levine, Front. Oncol. 2015, 5, DOI 10.3389/fonc.2015.00155.

[22] T. Tsuji, S. Ibaragi, G. Hu, Cancer Res. 2009, 69, 7135.

[23] T. Celià-Terrassa, Ó. Meca-Cortés, F. Mateo, A. M. de Paz, N. Rubio, A. Arnal-

Estapé, B. J. Ell, R. Bermudo, A. Díaz, M. Guerra-Rebollo, et al., J. Clin. Invest. 2012, 122, 1849.

[24] S. Y. Wong, R. O. Hynes, Cell Cycle Georget. Tex 2006, 5, 812.

[25] T. P. Butler, P. M. Gullino, Cancer Res. 1975, 35, 512.

[26] P. Paoli, E. Giannoni, P. Chiarugi, Biochim. Biophys. Acta BBA - Mol. Cell Res. 2013, $1833,3481$.

[27] M. Mohme, S. Riethdorf, K. Pantel, Nat. Rev. Clin. Oncol. 2017, 14, 155.

[28] S. Meng, D. Tripathy, E. P. Frenkel, S. Shete, E. Z. Naftalis, J. F. Huth, P. D. Beitsch, M. Leitch, S. Hoover, D. Euhus, et al., Clin. Cancer Res. 2004, 10, 8152.

[29] J. Ewing, Neoplastic Diseases; a Treatise on Tumors, Philadelphia London, W. B.

Saunders Company, 1922.

[30] P. Gassmann, A. Hemping-Bovenkerk, S. T. Mees, J. Haier, Int. J. Colorectal Dis. 2009, 24, 851 .

[31] L. Weiss, Clin. Exp. Metastasis 1992, 10, 191.

[32] G. Disibio, S. W. French, Arch. Pathol. Lab. Med. 2008, 132, 931.

[33] A. F. Chambers, A. C. Groom, I. C. MacDonald, Nat. Rev. Cancer 2002, 2, 563.

[34] G. Follain, N. Osmani, A. S. Azevedo, G. Allio, L. Mercier, M. A. Karreman, G.

Solecki, M. J. G. Leòn, O. Lefebvre, N. Fekonja, et al., Dev. Cell 2018, 45, 33.

[35] J. Li, M. R. King, Front. Oncol. 2012, 2, DOI 10.3389/fonc.2012.00079.

[36] C. L. Chaffer, R. A. Weinberg, Science 2011, 331, 1559.

[37] M.-Y. Kim, T. Oskarsson, S. Acharyya, D. X. Nguyen, X. H.-F. Zhang, L. Norton, J. Massagué, Cell 2009, 139, 1315.

[38] I. J. Fidler, JNCI J. Natl. Cancer Inst. 1970, 45, 773.

[39] K. J. Luzzi, I. C. MacDonald, E. E. Schmidt, N. Kerkvliet, V. L. Morris, A. F.

Chambers, A. C. Groom, Am. J. Pathol. 1998, 153, 865. 


\section{WILEY-VCH}

[40] J. Kim, C. W. Wong, J. D. Goldsmith, C. Song, W. Fu, M.-B. Allion, M. Herlyn, A. B. Al-Mehdi, R. J. Muschel, Cancer Lett. 2004, 213, 203.

[41] C. L. Hodgkinson, C. J. Morrow, Y. Li, R. L. Metcalf, D. G. Rothwell, F. Trapani, R. Polanski, D. J. Burt, K. L. Simpson, K. Morris, et al., Nat. Med. 2014, $20,897$.

[42] I. Baccelli, A. Schneeweiss, S. Riethdorf, A. Stenzinger, A. Schillert, V. Vogel, C.

Klein, M. Saini, T. Bäuerle, M. Wallwiener, et al., Nat. Biotechnol. 2013, 31, 539.

[43] P. E. Goss, A. F. Chambers, Nat. Rev. Cancer 2010, 10, 871.

[44] Y. Kang, K. Pantel, Cancer Cell 2013, 23, 573.

[45] R. N. Kaplan, R. D. Riba, S. Zacharoulis, A. H. Bramley, L. Vincent, C. Costa, D. D.

MacDonald, D. K. Jin, K. Shido, S. A. Kerns, et al., Nature 2005, 438, 820.

[46] Y. Liu, X. Cao, Cancer Cell 2016, 30, 668.

[47] S. A. Joosse, K. Pantel, Cancer Cell 2015, 28, 552.

[48] S. Braun, K. Pantel, P. Müller, W. Janni, F. Hepp, C. R. M. Kentenich, S. Gastroph, A. Wischnik, T. Dimpfl, G. Kindermann, et al., "Cytokeratin-Positive Cells in the Bone Marrow and Survival of Patients with Stage I, II, or III Breast Cancer," DOI

10.1056/NEJM200002243420801can be found under

https://www.nejm.org/doi/10.1056/NEJM200002243420801?url_ver=Z39.88-

2003\&rfr_id=ori\%3Arid\%3Acrossref.org\&rfr_dat=cr_pub\%3Dwww.ncbi.nlm.nih.gov, 2009.

[49] T. Fehm, A. Sagalowsky, E. Clifford, P. Beitsch, H. Saboorian, D. Euhus, S. Meng, L. Morrison, T. Tucker, N. Lane, et al., Clin. Cancer Res. 2002, 8, 2073.

[50] J. Weitz, P. Kienle, J. Lacroix, F. Willeke, A. Benner, T. Lehnert, C. Herfarth, M. von Knebel Doeberitz, Clin. Cancer Res. Off. J. Am. Assoc. Cancer Res. 1998, 4, 343.

[51] E. Racila, D. Euhus, A. J. Weiss, C. Rao, J. McConnell, L. W. M. M. Terstappen, J. W. Uhr, Proc. Natl. Acad. Sci. U. S. A. 1998, 95, 4589.

[52] R. Gertler, R. Rosenberg, K. Fuehrer, M. Dahm, H. Nekarda, J. R. Siewert, in Mol. Staging Cancer, Springer, Berlin, Heidelberg, 2003, pp. 149-155.

[53] R. Sabbatini, M. Federico, M. Morselli, R. Depenni, K. Cagossi, M. Luppi, G. Torelli, V. Silingardi, J. Clin. Oncol. Off. J. Am. Soc. Clin. Oncol. 2000, 18, 1914.

[54] M. Stroun, P. Anker, P. Maurice, J. Lyautey, C. Lederrey, M. Beljanski, Oncology 1989, 46, 318.

[55] G. D. Sorenson, D. M. Pribish, F. H. Valone, V. A. Memoli, D. J. Bzik, S. L. Yao, Cancer Epidemiol. Biomark. Prev. Publ. Am. Assoc. Cancer Res. Cosponsored Am. Soc. Prev. Oncol. 1994, 3, 67.

[56] J. C. M. Wan, C. Massie, J. Garcia-Corbacho, F. Mouliere, J. D. Brenton, C. Caldas, S. Pacey, R. Baird, N. Rosenfeld, Nat. Rev. Cancer 2017, 17, 223.

[57] N. Kosaka, Y. Yoshioka, Y. Fujita, T. Ochiya, J. Clin. Invest. n.d., 126, 1163.

[58] A. Becker, B. K. Thakur, J. M. Weiss, H. S. Kim, H. Peinado, D. Lyden, Cancer Cell 2016, 30, 836 .

[59] L. A. Diaz, A. Bardelli, J. Clin. Oncol. 2014, 32, 579.

[60] F. Mouliere, N. Rosenfeld, Proc. Natl. Acad. Sci. U. S. A. 2015, 112, 3178.

[61] F. Leung, V. Kulasingam, E. P. Diamandis, D. S. B. Hoon, K. Kinzler, K. Pantel, C. Alix-Panabières, Clin. Chem. 2016, 62, 1054.

[62] Y. H. Soung, S. Ford, V. Zhang, J. Chung, Cancers 2017, 9, DOI

10.3390/cancers9010008.

[63] J. Ko, E. Carpenter, D. Issadore, The Analyst 2016, 141, 450.

[64] T. Brodbeck, N. Nehmann, A. Bethge, G. Wedemann, U. Schumacher, Mol. Cancer 2014, 13, 244.

[65] A. W. Lambert, D. R. Pattabiraman, R. A. Weinberg, Cell 2017, 168, 670.

[66] J. D. Spicer, B. McDonald, J. J. Cools-Lartigue, S. C. Chow, B. Giannias, P. Kubes, L. E. Ferri, Cancer Res. 2012, 72, 3919. 


\section{WILEY-VCH}

[67] D. L. Adams, S. S. Martin, R. K. Alpaugh, M. Charpentier, S. Tsai, R. C. Bergan, I. M. Ogden, W. Catalona, S. Chumsri, C.-M. Tang, et al., Proc. Natl. Acad. Sci. U. S. A. 2014, $111,3514$.

[68] M. Yan, P. Jurasz, Biochim. Biophys. Acta BBA - Mol. Cell Res. 2016, 1863, 392.

[69] G. J. Caine, P. S. Stonelake, G. Y. Lip, S. T. Kehoe, Neoplasia N. Y. N 2002, 4, 465.

[70] J. S. Palumbo, K. E. Talmage, J. V. Massari, C. M. L. Jeunesse, M. J. Flick, K. W.

Kombrinck, M. Jirousková, J. L. Degen, Blood 2005, 105, 178.

[71] C. Philippe, B. Philippe, B. Fouqueray, J. Perez, M. Lebret, L. Baud, Am. J. Pathol. 1993, 143, 1713.

[72] F. R. Rickles, A. Falanga, Thromb. Res. 2001, 102, V215.

[73] M. Labelle, S. Begum, R. O. Hynes, Cancer Cell 2011, 20, 576.

[74] D. Wirtz, K. Konstantopoulos, P. C. Searson, Nat. Rev. Cancer 2011, 11, 512.

[75] J. M. Barnes, J. T. Nauseef, M. D. Henry, PLoS ONE 2012, 7, DOI

10.1371/journal.pone.0050973.

[76] A. Fu, S. Ma, N. Wei, B. X. Xuan Tan, E. Y. Tan, K. Q. Luo, Oncotarget 2016, 7, 50239.

[77] S. Regmi, A. Fu, K. Q. Luo, Sci. Rep. 2017, 7, 39975.

[78] A. Fabisiewicz, E. Grzybowska, Med. Oncol. 2017, 34, 12.

[79] D. Marrinucci, K. Bethel, R. H. Bruce, D. N. Curry, B. Hsieh, M. Humphrey, R. T.

Krivacic, J. Kroener, L. Kroener, A. Ladanyi, et al., Hum. Pathol. 2007, 38, 514.

[80] N. Aceto, A. Bardia, D. T. Miyamoto, M. C. Donaldson, B. S. Wittner, J. A. Spencer, M. Yu, A. Pely, A. Engstrom, H. Zhu, et al., Cell 2014, 158, 1110.

[81] A. F. Sarioglu, N. Aceto, N. Kojic, M. C. Donaldson, M. Zeinali, B. Hamza, A.

Engstrom, H. Zhu, T. K. Sundaresan, D. T. Miyamoto, et al., Nat. Methods 2015, 12, 685.

[82] M. Yu, A. Bardia, B. S. Wittner, S. L. Stott, M. E. Smas, D. T. Ting, S. J. Isakoff, J. C. Ciciliano, M. N. Wells, A. M. Shah, et al., Science 2013, 339, 580.

[83] M. Giuliano, A. Shaikh, H. C. Lo, G. Arpino, S. D. Placido, X. H. Zhang, M.

Cristofanilli, R. Schiff, M. V. Trivedi, Cancer Res. 2018, DOI 10.1158/0008-5472.CAN-172748 .

[84] H. C. Engell, Ann. Surg. 1959, 149, 457.

[85] A. A. Ross, B. W. Cooper, H. M. Lazarus, W. Mackay, T. J. Moss, N. Ciobanu, M. S. Tallman, M. J. Kennedy, N. E. Davidson, D. Sweet, Blood 1993, 82, 2605.

[86] N, I. Db, J. Mol. Biomark. Diagn. 2017, 8, 1.

[87] D. Marrinucci, K. Bethel, D. Lazar, J. Fisher, E. Huynh, P. Clark, R. Bruce, J. Nieva, P. Kuhn, J. Oncol. 2010, 2010, DOI 10.1155/2010/861341.

[88] D. Marrinucci, K. Bethel, M. Luttgen, R. H. Bruce, J. Nieva, P. Kuhn, Arch. Pathol. Lab. Med. 2009, 133, 1468.

[89] S. H. Seal, Cancer 1964, 17, 637.

[90] N. H. Stoecklein, J. C. Fischer, D. Niederacher, L. W. M. M. Terstappen, Expert Rev. Mol. Diagn. 2016, 16, 147.

[91] S. Suresh, Nat. Nanotechnol. 2007, 2, 748.

[92] S. E. Cross, Y.-S. Jin, J. Rao, J. K. Gimzewski, Nat. Nanotechnol. 2007, 2, 780.

[93] V. Swaminathan, K. Mythreye, E. T. O’Brien, A. Berchuck, G. C. Blobe, R. Superfine, Cancer Res. 2011, 71, 5075.

[94] C. L. Yankaskas, K. N. Thompson, C. D. Paul, M. I. Vitolo, P. Mistriotis, A. Mahendra, V. K. Bajpai, D. J. Shea, K. M. Manto, A. C. Chai, et al., Nat. Biomed. Eng. 2019, 3,452 .

[95] V. K. Chivukula, B. L. Krog, J. T. Nauseef, M. D. Henry, S. C. Vigmostad, "Alterations in cancer cell mechanical properties after fluid shear stress exposure: a micropipette aspiration study," DOI 10.2147/CHC.S71852can be found under 


\section{WILEY-VCH}

https://www.dovepress.com/alterations-in-cancer-cell-mechanical-properties-after-fluidshear-str-peer-reviewed-fulltext-article-CHC, 2015.

[96] K. A. Rejniak, Front. Oncol. 2012, 2, DOI 10.3389/fonc.2012.00111.

[97] M. F. Coughlin, D. R. Bielenberg, G. Lenormand, M. Marinkovic, C. G. Waghorne, B. R. Zetter, J. J. Fredberg, Clin. Exp. Metastasis 2013, 30, DOI 10.1007/s10585-012-9531-z.

[98] Q. Guo, S. Park, H. Ma, Lab. Chip 2012, 12, 2687.

[99] M. J. Rosenbluth, W. A. Lam, D. A. Fletcher, Biophys. J. 2006, 90, 2994.

[100] J. S. Bagnall, S. Byun, S. Begum, D. T. Miyamoto, V. C. Hecht, S. Maheswaran, S. L. Stott, M. Toner, R. O. Hynes, S. R. Manalis, Sci. Rep. 2015, 5, 18542.

[101] "Tumor Markers," can be found under https://www.cancer.gov/aboutcancer/diagnosis-staging/diagnosis/tumor-markers-fact-sheet, n.d.

[102] G. Barriere, P. Fici, G. Gallerani, F. Fabbri, W. Zoli, M. Rigaud, Ann. Transl. Med. 2014, 2, DOI 10.3978/j.issn.2305-5839.2014.10.04.

[103] S. Gkountela, B. Szczerba, C. Donato, N. Aceto, ESMO Open 2016, 1, e000078.

[104] A. Armstrong, S. L. Eck, Cancer Biol. Ther. 2003, 2, 320.

[105] C. Raimondi, C. Nicolazzo, A. Gradilone, Chin. J. Cancer Res. 2015, 27, 461.

[106] M.-E. Francart, J. Lambert, A. M. Vanwynsberghe, E. W. Thompson, M. Bourcy, M. Polette, C. Gilles, Dev. Dyn. Off. Publ. Am. Assoc. Anat. 2018, 247, 432.

[107] C. G. Rao, D. Chianese, G. V. Doyle, M. C. Miller, T. Russell, R. A. Sanders, L. W. M. M. Terstappen, Int. J. Oncol. 2005, 27, 49.

[108] F. Li, B. Tiede, J. Massagué, Y. Kang, Cell Res. 2007, 17, 3.

[109] W. Li, H. Ma, J. Zhang, L. Zhu, C. Wang, Y. Yang, Sci. Rep. 2017, 7, 13856.

[110] S. L. Stott, C.-H. Hsu, D. I. Tsukrov, M. Yu, D. T. Miyamoto, B. A. Waltman, S. M. Rothenberg, A. M. Shah, M. E. Smas, G. K. Korir, et al., Proc. Natl. Acad. Sci. U. S. A. 2010, $107,18392$.

[111] J. G. Moreno, S. M. O’Hara, S. Gross, G. Doyle, H. Fritsche, L. G. Gomella, L. W. M. M. Terstappen, Urology 2001, 58, 386.

[112] C. Renier, E. Pao, J. Che, H. E. Liu, C. A. Lemaire, M. Matsumoto, M. Triboulet, S. Srivinas, S. S. Jeffrey, M. Rettig, et al., Npj Precis. Oncol. 2017, 1, 15.

[113] S. Park, R. R. Ang, S. P. Duffy, J. Bazov, K. N. Chi, P. C. Black, H. Ma, PLoS ONE 2014, 9, DOI 10.1371/journal.pone.0085264.

[114] E. Ozkumur, A. M. Shah, J. C. Ciciliano, B. L. Emmink, D. T. Miyamoto, E. Brachtel, M. Yu, P. Chen, B. Morgan, J. Trautwein, et al., Sci. Transl. Med. 2013, 5, 179 ra47.

[115] W. J. Allard, J. Matera, M. C. Miller, M. Repollet, M. C. Connelly, C. Rao, A. G. J. Tibbe, J. W. Uhr, L. W. M. M. Terstappen, Clin. Cancer Res. 2004, 10, 6897.

[116] K. G. Phillips, A. Kolatkar, K. J. Rees, R. Rigg, D. Marrinucci, M. Luttgen, K. Bethel, P. Kuhn, O. J. T. McCarty, Front. Oncol. 2012, 2, DOI 10.3389/fonc.2012.00096.

[117] K. G. Phillips, C. R. Velasco, J. Li, A. Kolatkar, M. Luttgen, K. Bethel, B. Duggan, P. Kuhn, O. J. T. McCarty, Front. Oncol. 2012, 2, DOI 10.3389/fonc.2012.00072.

[118] M. M. Ferreira, V. C. Ramani, S. S. Jeffrey, Mol. Oncol. 2016, 10, 374.

[119] A. H. Talasaz, A. A. Powell, D. E. Huber, J. G. Berbee, K.-H. Roh, W. Yu, W. Xiao, M. M. Davis, R. F. Pease, M. N. Mindrinos, et al., Proc. Natl. Acad. Sci. U. S. A. 2009, 106, 3970.

[120] J. Autebert, B. Coudert, J. Champ, L. Saias, E. T. Guneri, R. Lebofsky, F.-C. Bidard, J.-Y. Pierga, F. Farace, S. Descroix, et al., Lab. Chip 2015, 15, 2090.

[121] C. M. Earhart, R. J. Wilson, R. L. White, N. Pourmand, S. X. Wang, J. Magn. Magn. Mater. 2009, 321, 1436.

[122] S. Nagrath, L. V. Sequist, S. Maheswaran, D. W. Bell, D. Irimia, L. Ulkus, M. R.

Smith, E. L. Kwak, S. Digumarthy, A. Muzikansky, et al., Nature 2007, 450, 1235.

[123] W. Sheng, O. O. Ogunwobi, T. Chen, J. Zhang, T. J. George, C. Liu, Z. H. Fan, Lab. Chip 2014, 14, 89. 


\section{WILEY-VCH}

[124] J. P. Gleghorn, E. D. Pratt, D. Denning, H. Liu, N. H. Bander, S. T. Tagawa, D. M. Nanus, P. A. Giannakakou, B. J. Kirby, Lab. Chip 2010, 10, 27.

[125] L. Zhao, Y.-T. Lu, F. Li, K. Wu, S. Hou, J. Yu, Q. Shen, D. Wu, M. Song, W.-H. OuYang, et al., Adv. Mater. 2013, 25, 2897.

[126] F. S. Mandlebaum, J. Lab. Clin. Med. 1917, 2, 580.

[127] L. S. Lim, M. Hu, M. C. Huang, W. C. Cheong, A. T. L. Gan, X. L. Looi, S. M.

Leong, E. S.-C. Koay, M.-H. Li, Lab. Chip 2012, 12, 4388.

[128] S. de Wit, G. van Dalum, A. T. M. Lenferink, A. G. J. Tibbe, T. J. N. Hiltermann, H.

J. M. Groen, C. J. M. van Rijn, L. W. M. M. Terstappen, Sci. Rep. 2015, 5, 12270.

[129] J. F. Swennenhuis, A. G. J. Tibbe, M. Stevens, M. R. Katika, J. van Dalum, H. D.

Tong, C. J. M. van Rijn, L. W. M. M. Terstappen, Lab. Chip 2015, 15, 3039.

[130] M. Hosokawa, T. Hayata, Y. Fukuda, A. Arakaki, T. Yoshino, T. Tanaka, T.

Matsunaga, Anal. Chem. 2010, 82, 6629.

[131] D. L. Adams, P. Zhu, O. V. Makarova, S. S. Martin, M. Charpentier, S. Chumsri, S.

Li, P. Amstutz, C.-M. Tang, RSC Adv. 2014, 9, 4334.

[132] S. Zheng, H. Lin, J.-Q. Liu, M. Balic, R. Datar, R. J. Cote, Y.-C. Tai, J. Chromatogr. A 2007, 1162, 154.

[133] R. A. Harouaka, M. D. Zhou, Y. T. Yeh, W. J. Khan, A. Das, X. Liu, C. C. Christ, D.

T. Dicker, T. S. Baney, J. T. Kaifi, et al., Clin. Chem. 2014, 60, 323.

[134] S. Zheng, H. K. Lin, B. Lu, A. Williams, R. Datar, R. J. Cote, Y.-C. Tai, Biomed. Microdevices 2011, 13, DOI 10.1007/s10544-010-9485-3.

[135] M.-D. Zhou, S. Hao, A. J. Williams, R. A. Harouaka, B. Schrand, S. Rawal, Z. Ao, R. Brenneman, E. Gilboa, B. Lu, et al., Sci. Rep. 2014, 4, srep07392.

[136] H. Mohamed, M. Murray, J. N. Turner, M. Caggana, J. Chromatogr. A 2009, 1216, 8289.

[137] S. J. Tan, L. Yobas, G. Y. H. Lee, C. N. Ong, C. T. Lim, Biomed. Microdevices 2009, 11,883 .

[138] J. S. Kuo, Y. Zhao, P. G. Schiro, L. Ng, D. S. W. Lim, J. P. Shelby, D. T. Chiu, Lab. Chip 2010, 10, 837.

[139] W. Beattie, X. Qin, L. Wang, H. Ma, Lab, Chip 2014, 14, 2657.

[140] D. D. Carlo, Lab. Chip 2009, 9, 3038.

[141] E. Sollier, D. E. Go, J. Che, D. R. Gossett, S. O’Byrne, W. M. Weaver, N. Kummer, M. Rettig, J. Goldman, N. Nickols, et al., Lab. Chip 2013, 14, 63.

[142] H. W. Hou, M. E. Warkiani, B. L. Khoo, Z. R. Li, R. A. Soo, D. S.-W. Tan, W.-T. Lim, J. Han, A. A. S. Bhagat, C. T. Lim, Sci. Rep. 2013, 3, 1259.

[143] K. Loutherback, J. D’Silya, L. Liu, A. Wu, R. H. Austin, J. C. Sturm, AIP Adv. 2012, 2, DOI 10.1063/1.4758131.

[144] S. H. Au, J. Edd, A. E. Stoddard, K. H. K. Wong, F. Fachin, S. Maheswaran, D. A.

Haber, S. L. Stott, R. Kapur, M. Toner, Sci. Rep. 2017, 7, 2433.

[145] N. M. Karabacak, P. S. Spuhler, F. Fachin, E. J. Lim, V. Pai, E. Ozkumur, J. M.

Martel, N. Kojic, K. Smith, P. Chen, et al., Nat. Protoc. 2014, 9, 694.

[146] V. Gupta, I. Jafferji, M. Garza, V. O. Melnikova, D. K. Hasegawa, R. Pethig, D. W. Davis, Biomicrofluidics 2012, 6, 024133.

[147] K. Pantel, E. Denève, D. Nocca, A. Coffy, J.-P. Vendrell, T. Maudelonde, S.

Riethdorf, C. Alix-Panabières, Clin. Chem. 2012, 58, 936.

[148] A. El-Heliebi, C. Hille, N. Laxman, J. Svedlund, C. Haudum, E. Ercan, T. Kroneis, S.

Chen, M. Smolle, C. Rossmann, et al., Clin. Chem. 2018, 64, 536.

[149] E. Andreopoulou, L.-Y. Yang, K. M. Rangel, J. M. Reuben, L. Hsu, S. Krishnamurthy, V. Valero, H. A. Fritsche, M. Cristofanilli, Int. J. Cancer n.d., 130, 1590.

[150] L. Xi, D. G. Nicastri, T. El-Hefnawy, S. J. Hughes, J. D. Luketich, T. E. Godfrey, Clin. Chem. 2007, 53, 1206. 


\section{WILEY-VCH}

[151] S. L. Stott, R. J. Lee, S. Nagrath, M. Yu, D. T. Miyamoto, L. Ulkus, E. J. Inserra, M. Ulman, S. Springer, Z. Nakamura, et al., Sci. Transl. Med. 2010, 2, 25 ra23.

[152] D. L. Evers, C. B. Fowler, B. R. Cunningham, J. T. Mason, T. J. O’Leary, J. Mol. Diagn. JMD 2011, 13, 282.

[153] O. Kim, D. Lee, A. C. Lee, Y. Lee, H. J. Bae, H.-B. Lee, R. N. Kim, W. Han, S.

Kwon, Small 2019, 15, 1902607.

[154] M. Yu, D. T. Ting, S. L. Stott, B. S. Wittner, F. Ozsolak, S. Paul, J. C. Ciciliano, M. E. Smas, D. Winokur, A. J. Gilman, et al., Nature 2012, 487, 510.

[155] G. M. Cann, Z. G. Gulzar, S. Cooper, R. Li, S. Luo, M. Tat, S. Stuart, G. Schroth, S. Srinivas, M. Ronaghi, et al., PLOS ONE 2012, 7, e49144.

[156] D. Boral, M. Vishnoi, H. N. Liu, W. Yin, M. L. Sprouse, A. Scamardo, D. S. Hong, T. Z. Tan, J. P. Thiery, J. C. Chang, et al., Nat. Commun. 2017, 8, 196.

[157] M. Cristofanilli, G. T. Budd, M. J. Ellis, A. Stopeck, J. Matera, M. C. Miller, J. M. Reuben, G. V. Doyle, W. J. Allard, L. W. M. M. Terstappen, et al., "Circulating Tumor Cells, Disease Progression, and Survival in Metastatic Breast Cancer," DOI 10.1056/NEJMoa040766can be found under https://www.nejm.org/doi/10.1056/NEJMoa040766?url_ver=Z39.882003\&rfr_id=ori\%3Arid\%3Acrossref.org\&rfr_dat=cr_pub\%3Dwww.ncbi.nlm.nih.gov, 2009. [158] J. S. de Bono, H. I. Scher, R. B. Montgomery, C. Parker, M. C. Miller, H. Tissing, G. V. Doyle, L. W. W. M. Terstappen, K. J. Pienta, D. Raghavan, Clin. Cancer Res. 2008, 14, 6302.

[159] S. J. Cohen, C. J. A. Punt, N. Iannotti, B. H. Saidman, K. D. Sabbath, N. Y. Gabrail, J. Picus, M. Morse, E. Mitchell, M. C. Miller, et al., J. Clin. Oncol. 2008, 26, 3213.

[160] V. Hofman, M. I. Ilie, E. Long, E. Selva, C. Bonnetaud, T. Molina, N. Vénissac, J. Mouroux, P. Vielh, P. Hofman, Int. J. Cancer n.d., 129, 1651.

[161] T. Naito, F. Tanaka, A. Ono, K. Yoneda, T. Takahashi, H. Murakami, Y. Nakamura, A. Tsuya, H. Kenmotsu, T. Shukuya, et al., J. Thorac. Oncol. 2012, 7, 512.

[162] A. Poveda, S. B. Kaye, R. McCormack, S. Wang, T. Parekh, D. Ricci, C. A.

Lebedinsky, J. C. Tercero, P. Zintl, B. J. Monk, Gynecol. Oncol. 2011, 122, 567.

[163] E. Rossi, M. Fassan, M. Aieta, F. Zilio, R. Celadin, M. Borin, A. Grassi, L. Troiani, U. Basso, C. Barile, et al., Br. J. Cancer 2012, 107, 1286.

[164] D. Klinac, E. S. Gray, J. B. Freeman, A. Reid, S. Bowyer, M. Millward, M. Ziman, BMC Cancer 2014, 14, 423.

[165] B. Rack, C. Schindlbeck, J. Jückstock, U. Andergassen, P. Hepp, T. Zwingers, T. W. P. Friedl, R. Lorenz, H. Tesch, P. A. Fasching, et al., JNCI J. Natl. Cancer Inst. 2014, 106, DOI 10.1093/jnci/dju066.

[166] M. Thalgott, B. Rack, T. Horn, M. M. Heck, M. Eiber, H. Kübler, M. Retz, J. E. Gschwend, U. Andergassen, R. Nawroth, Anticancer Res. 2015, 35, 5679.

[167] E. Denève, S. Riethdorf, J. Ramos, D. Nocca, A. Coffy, J.-P. Daurès, T. Maudelonde, J.-M. Fabre, K. Pantel, C. Alix-Panabières, Clin. Chem. 2013, 59, 1384.

[168] P. Gazzaniga, E. de Berardinis, C. Raimondi, A. Gradilone, G. M. Busetto, E. De Falco, C. Nicolazzo, R. Giovannone, V. Gentile, E. Cortesi, et al., Int. J. Cancer 2014, 135, 1978.

[169] K. Schulze, C. Gasch, K. Staufer, B. Nashan, A. W. Lohse, K. Pantel, S. Riethdorf, H. Wege, Int. J. Cancer n.d., 133, 2165.

[170] F.-C. Bidard, D. J. Peeters, T. Fehm, F. Nolé, R. Gisbert-Criado, D. Mavroudis, S. Grisanti, D. Generali, J. A. Garcia-Saenz, J. Stebbing, et al., Lancet Oncol. 2014, 15, 406. [171] H. I. Scher, G. Heller, A. Molina, G. Attard, D. C. Danila, X. Jia, W. Peng, S. K. Sandhu, D. Olmos, R. Riisnaes, et al., J. Clin. Oncol. Off. J. Am. Soc. Clin. Oncol. 2015, 33, 1348 . 


\section{WILEY-VCH}

[172] F.-C. Bidard, C. Mathiot, A. Degeorges, M.-C. Etienne-Grimaldi, R. Delva, X. Pivot, C. Veyret, L. Bergougnoux, P. de Cremoux, G. Milano, et al., Ann. Oncol. 2010, 21, 1765.

[173] A. Giordano, M. Giuliano, M. D. Laurentiis, A. Eleuteri, F. Iorio, R. Tagliaferri, G. N. Hortobagyi, L. Pusztai, S. D. Placido, K. Hess, et al., Breast Cancer Res. Treat. 2011, 129, 451.

[174] F.-C. Bidard, T. Fehm, M. Ignatiadis, J. B. Smerage, C. Alix-Panabières, W. Janni, C. Messina, C. Paoletti, V. Müller, D. F. Hayes, et al., Cancer Metastasis Rev. 2013, 32, 179.

[175] N.d.

[176] G. Méhes, A. Witt, E. Kubista, P. F. Ambros, Am. J. Pathol. 2001, 159, 17.

[177] A. Ring, N. Mineyev, W. Zhu, E. Park, C. Lomas, V. Punj, M. Yu, D. Barrak, V.

Forte, T. Porras, et al., Oncotarget 2015, 6, 44623.

[178] I. H. Benoy, H. Elst, P. Van Dam, S. Scharpé, E. Van Marck, P. B. Vermeulen, L. Y. Dirix, Clin. Chem. Lab. Med. 2006, 44, 1082.

[179] T. J. Molloy, A. J. Bosma, L. J. van't Veer, Breast Cancer Res. Treat. 2008, 112, 297. [180] S. Becker, G. Becker-Pergola, T. Fehm, D. Wallwiener, E.-F. Solomayer, Clin. Chem. 2004, 50, 785 .

[181] K. H. K. Wong, R. D. Sandlin, T. R. Carey, K. L. Miller, A. T. Shank, R. Oklu, S. Maheswaran, D. A. Haber, D. Irimia, S. L. Stott, et al., Sci. Rep. 2016, 6, 21023.

[182] J. Qin, J. R. Alt, B. A. Hunsley, T. L. Williams, M. R. Fernando, Cancer Cell Int. 2014, 14, 23.

[183] K. H. K. Wong, S. N. Tessier, D. T. Miyamoto, K. L. Miller, L. D. Bookstaver, T. R. Carey, C. J. Stannard, V. Thapar, E. C. Tai, K. D. Vo, et al., Nat. Commun. 2017, 8, 1733. [184] F. Medeiros, C. T. Rigl, G. G. Anderson, S. H. Becker, K. C. Halling, Arch. Pathol. Lab. Med. 2007, 131, 1805.

[185] M. M. Reinholz, K. A. Kitzmann, K. Tenner, D. Hillman, A. C. Dueck, T. J. Hobday, D. W. Northfelt, A. Moreno-Aspitia, V. Roy, B. LaPlant, et al., Clin. Cancer Res. Off. J. Am. Assoc. Cancer Res. 2011, 17, 7183.

[186] F. A. W. Coumans, S. T. Ligthart, J. W. Uhr, L. W. M. M. Terstappen, Clin. Cancer Res. 2012, 18, 5711.

[187] Z. S. Lalmahomed, J. Kraan, J. W. Gratama, B. Mostert, S. Sleijfer, C. Verhoef, J. Clin. Oncol. 2010, 28, e288.

[188] A. G. J. Tibbe, M. C. Miller, L. W. M. M. Terstappen, Cytometry A 2007, 71A, 154.

[189] J. I. Rosenblatt, J. A. Hokanson, S. R. McLaughlin, J. F. Leary, Cytometry 1997, 27, 233.

[190] A. L. Allan, M. Keeney, J. Oncol. 2010, 2010, 426218.

[191] N. Saucedo-Zeni, S. Mewes, R. Niestroj, L. Gasiorowski, D. Murawa, P. Nowaczyk, T. Tomasi, E. Weber, G. Dworacki, N. G. Morgenthaler, et al., Int. J. Oncol. 2012, 41, 1241. [192] S. Chen, A. El-Heliebi, G. Tauber, T. Langsenlehner, M. Pötscher, K. Kashofer, Z. T. Czyż, B. Polzer, S. Riethdorf, A. Kuske, et al., Sci. Rep. 2017, 7, 43424.

[193] D. Mandair, C. Vesely, L. Ensell, H. Lowe, V. Spanswick, J. A. Hartley, M. E. Caplin, T. Meyer, Endocr. Relat. Cancer 2016, 23, L29.

[194] T. M. Gorges, N. Penkalla, T. Schalk, S. A. Joosse, S. Riethdorf, J. Tucholski, K. Lücke, H. Wikman, S. Jackson, N. Brychta, et al., Clin. Cancer Res. Off. J. Am. Assoc.

Cancer Res. 2016, 22, 2197.

[195] A. Markou, M. Lazaridou, P. Paraskevopoulos, S. Chen, M. Świerczewska, J. Budna, A. Kuske, T. M. Gorges, S. A. Joosse, T. Kroneis, et al., Clin. Chem. 2017, clinchem.2017.275503.

[196] A. Kuske, T. M. Gorges, P. Tennstedt, A.-K. Tiebel, R. Pompe, F. Preißer, S. Prues, M. Mazel, A. Markou, E. Lianidou, et al., Sci. Rep. 2016, 6, 39736. 


\section{WILEY-VCH}

[197] J. C. Fischer, D. Niederacher, S. A. Topp, E. Honisch, S. Schumacher, N. Schmitz, L. Z. Föhrding, C. Vay, I. Hoffmann, N. S. Kasprowicz, et al., Proc. Natl. Acad. Sci. 2013, 110, 16580.

[198] T. H. Kim, Y. Wang, C. R. Oliver, D. H. Thamm, L. Cooling, C. Paoletti, K. J. Smith, S. Nagrath, D. F. Hayes, Nat. Commun. 2019, 10, 1.

[199] E. I. Galanzha, E. V. Shashkov, T. Kelly, J.-W. Kim, L. Yang, V. P. Zharov, Nat.

Nanotechnol. 2009, 4, 855.

[200] Y.-C. Chang, J. Y. Ye, T. P. Thomas, Z. Cao, A. Kotlyar, E. R. Tkaczyk, J. R. Baker, T. B. Norris, J. Biomed. Opt. 2010, 15, 047004.

[201] W. He, H. Wang, L. C. Hartmann, J.-X. Cheng, P. S. Low, Proc. Natl. Acad. Sci. U. S. A. 2007, 104, 11760 .

[202] S. M. Azarin, J. Yi, R. M. Gower, B. A. Aguado, M. E. Sullivan, A. G. Goodman, E. J. Jiang, S. S. Rao, Y. Ren, S. L. Tucker, et al., Nat. Commun. 2015, 6, ncomms9094. [203] E. Bou, A. K. Jiménez-Zenteno, A. Estève, D. Bourrier, C. Vieu, A. Cerf, Microelectron. Eng. 2019, 213, 69.

[204] S. M. Leong, K. M. Tan, H. W. Chua, D. Tan, D. Fareda, S. Osmany, M.-H. Li, S.

Tucker, E. S. Koay, J. Hematol. Oncol.J Hematol Oncol 2015, 8, 75.

[205] C. Alix-Panabières, in Minimal Residual Dis. Circ. Tumor Cells Breast Cancer, Springer, Berlin, Heidelberg, 2012, pp. 69-76.

[206] C. Alix-Panabières, K. Bartkowiak, K. Pantel, Mol. Oncol. 2016, 10, 443. 


\section{WILEY-VCH}

a Primary tumour

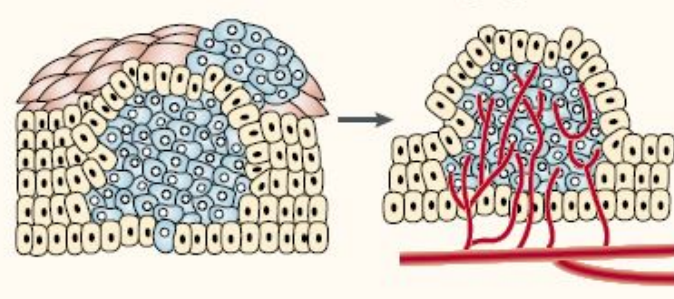

c Detachment/ invasion d Embolism/circulation

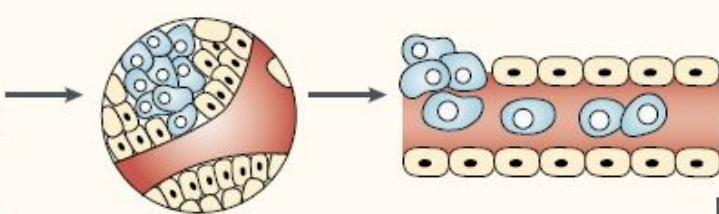

Lymphatics,

venules,

capillaries
Interaction with platelets, lymphocytes and other blood components

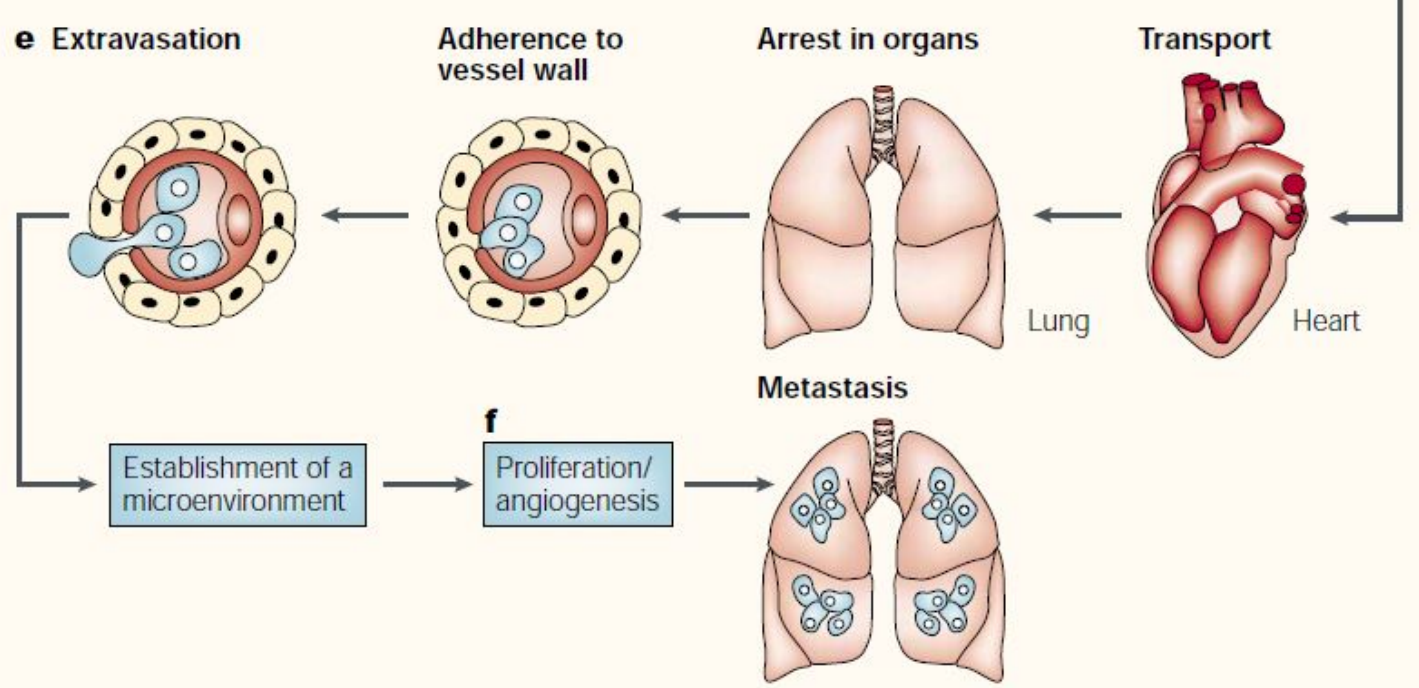

Figure 1. The main steps in the formation of metastasis. ${ }^{[15]}$ Reprinted by permission from Springer Nature from IJ Fidler, Nature Reviews Cancer, Copyright (2003). 


\section{WILEY-VCH}

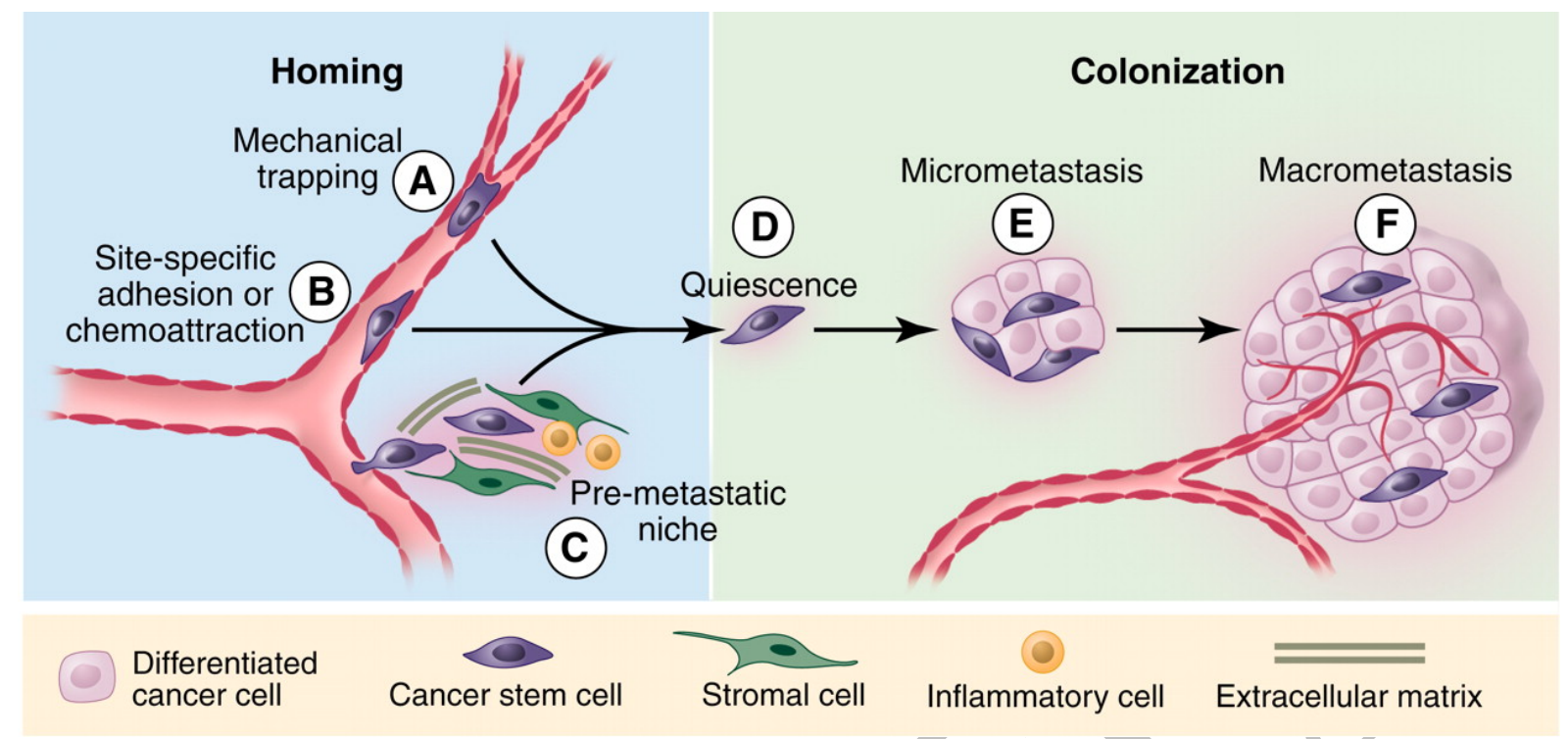

Figure 2. Homing and colonization of circulating tumor cells. Figure extracted from C.L.

Chaffer and R.A Weinberg, Science, 2011 ${ }^{[36]}$ Reprinted with permission from AAAS. 


\section{WILEY-VCH}

\section{Whole blood}

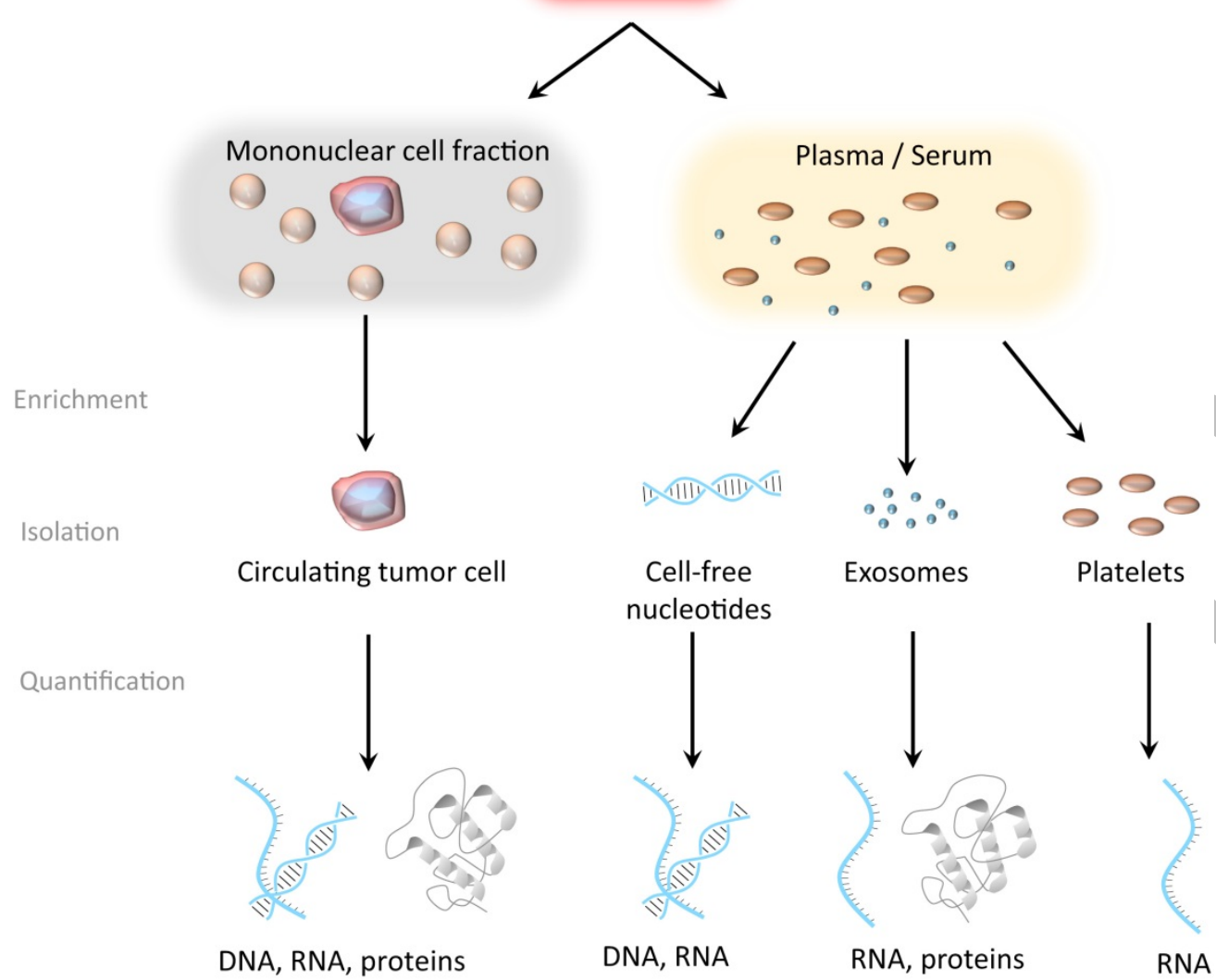

Figure 3. Tumor-derived materials of liquid biopsy. ${ }^{[47]}$ Reprinted from S.A. Joosse and K.

Pantel, Cancer Cell, 2015 with permission from Elsevier. 


\section{WILEY-VCH}

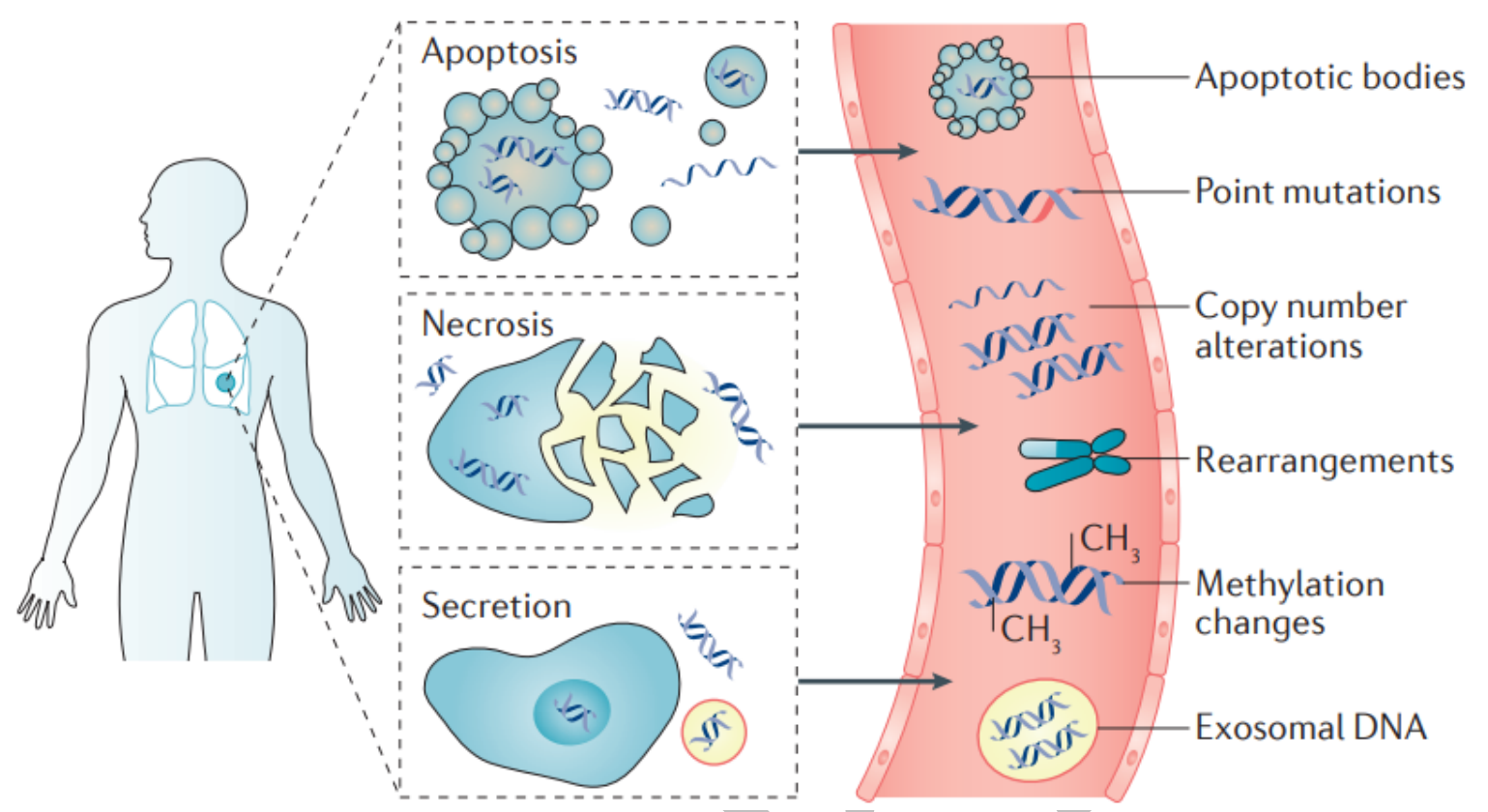

Figure 4. Origins and range of alterations in cell-free DNA. ${ }^{[56]}$ Reprinted by permission from Springer Nature from J.C.M. Wan, Nature Reviews Cancer, Copyright (2017). 


\section{WILEY-VCH}

\begin{tabular}{|c|c|c|c|c|}
\hline Cell Type & Value & $\begin{array}{c}\text { Isolation/Detection } \\
\text { Platform }\end{array}$ & Isolation Principle & Reference \\
\hline \multicolumn{5}{|c|}{ Diameter, $\mu \mathrm{m}$} \\
\hline Prostate CTC & $8-16$ & HB-Chip & $\begin{array}{l}\text { Antibody-coated Chip } \\
\text { Surface, EpCAM }\end{array}$ & $\begin{array}{l}\text { Stott et al., } \\
\text { 2010. }\end{array}$ \\
\hline Prostate CTC & $\begin{array}{c}3->10 \\
3-10(150 / 199 \text { counts }) \\
>10(49 / 199 \text { counts })\end{array}$ & FACS & $\begin{array}{l}\text { Positive Immunomagnetic } \\
\text { Sorting, EpCAM }\end{array}$ & $\begin{array}{l}\text { Moreno et al., } \\
\text { 2001. }\end{array}$ \\
\hline Prostate CTC & $\begin{array}{c}21.1 \pm 8.4 \\
15.9 \pm 6.9, \mathrm{CK}+ \\
26.2 \pm 6.5, \mathrm{CK}-\end{array}$ & Vortex HT & Size-based Sorting & $\begin{array}{l}\text { Renier et al., } \\
2017 .^{[112]}\end{array}$ \\
\hline Prostate CTC & $7.97 \pm 1.81$ & CellSearch & $\begin{array}{c}\text { Positive Immunomagnetic } \\
\text { Sorting, EpCAM }\end{array}$ & $\begin{array}{l}\text { Park et al., } \\
2014 .{ }^{[113]}\end{array}$ \\
\hline $\begin{array}{l}\text { Melanoma } \\
\text { CTC }\end{array}$ & $>12$ & CTC-iChip & $\begin{array}{c}\text { Negative Immunomagnetic } \\
\text { Sorting, CD45 }\end{array}$ & $\begin{array}{l}\text { Ozkumur et } \\
\text { al., 2013. }{ }^{[114]}\end{array}$ \\
\hline Breast CTC & $9-19$ & CTC-iChip & $\begin{array}{c}\text { Negative Immunomagnetic } \\
\text { Sorting, CD45 }\end{array}$ & $\begin{array}{l}\text { Ozkumur et } \\
\text { al., 2013. } .^{[114]}\end{array}$ \\
\hline Breast CTC & $\begin{array}{c}32.0 \pm 5.8, \\
\text { Primary Tumor } \\
33.9 \pm 8.3 \\
\text { Metastatic Disease } \\
29.8 \pm 6.5 \\
\text { Dormancy Candidates }\end{array}$ & & $\begin{array}{l}\text { Positive Immunomagnetic } \\
\text { Sorting, EpCAM }\end{array}$ & $\begin{array}{l}\text { Meng et al., } \\
\text { 2004. }\end{array}$ \\
\hline $\begin{array}{l}\text { Various } \\
\text { metastatic } \\
\text { carcinomas }\end{array}$ & $<4->30$ & & $\begin{array}{l}\text { Positive Immunomagnetic } \\
\text { Sorting, EpCAM }\end{array}$ & $\begin{array}{l}\text { Allard et al., } \\
\text { 2004. }\end{array}$ \\
\hline \multicolumn{5}{|c|}{ Volume, $\mu \mathrm{m}^{3}$} \\
\hline Breast CTC & $851.6 \pm 45.8$ & & & $\begin{array}{l}\text { Phillips et al., } \\
\text { 2012. }\end{array}$ \\
\hline Ovarian СТC & $518.3 \pm 24$ & HD-CTC & & $\begin{array}{l}\text { Phillips et } \\
\text { al.,2012. }^{[117]}\end{array}$ \\
\hline Leukocyte & $234.1 \pm 4.1$ & & & $\begin{array}{l}\text { Phillips et al., } \\
\text { 2012. }\end{array}$ \\
\hline Erythrocyte & $100.6 \pm 4.0$ & & & $\begin{array}{c}\text { Phillips et al., } \\
\text { 2012. }{ }^{[116]}\end{array}$ \\
\hline
\end{tabular}

Table 1.1 Biophysical properties of CTCs for different carcinomas. Values are means $\pm \mathrm{SD}$, unless otherwise noted. HB-Chip: Herringbone-Chip, HD-CTC: high-definition CTC, CTCiChip: inertial focusing CTC-Chip, MACS: high-gradient magnetic cell sorting, FACS: fluorescence-activated cell sorting, Vortex HT: High Throughput Vortex Chip, CK+: Positive to Cytokeratin, CK-: Negative to Cytokeratin. 


\section{WILEY-VCH}

If circulating tumor cells (CTCs) relevance as biomarkers is not questioned, their adoption in the clinics is still hampered by various biological implications and technological bottlenecks here reviewed. Overcoming these considerations could unveil many aspects of the metastatic process and offer a route towards routine implementation of CTC-based liquid biopsy to guide medical decisions and improve patient care.

\section{CTC-based Liquid Biopsy}

A. K. Jiménez-Zenteno, A. Cerf*

Liquid biopsy based on circulating cancer-associated cells: bridging the gap from an emerging concept to a mainstream tool in precision medicine.

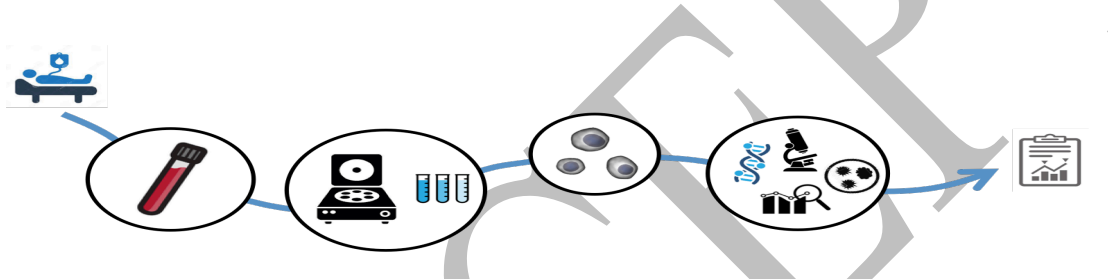

